\title{
Dissection of Synechococcus Rubisco Large Subunit Sections Involved in Holoenzyme Formation in Escherichia coli by Combinatorial Section Swapping and Sequence Analyses
}

(Pembahagian Synechococcus Rubisco Seksyen Subunit Besar Terlibat dalam Pembentukan holoenzim dalam Escherichia coli oleh Seksyen Kombinatori Tertukar dan Jujukan Analisis)

\author{
YeE Hung Yeap, Teng Wei KoAy, Hann Ling Wong \& Boon Hoe LiM*
}

\begin{abstract}
ABSTRAK
Engineering the $\mathrm{CO}_{2}$-fixing enzyme ribulose-1,5-bisphosphate carboxylase/oxygenase (Rubisco) to improve photosynthesis has long been sought. Rubisco large subunits (RbcL) are highly-conserved but because of certain undefined sequence differences, plant Rubisco research cannot fully utilise the robust heterologous Escherichia coli expression system and its GroEL folding machinery. Previously, a series of chimeric cyanobacteria Synechococcus elongatus Rubisco, incorporated with sequences from the green alga Chlamydomonas reinhardtii, were expressed in $\mathrm{E}$. coli; differences in RbcL sections essential for holoenzyme formation were pinpointed. In this study, the remaining sections, presumably not crucial for holoenzyme formation and also the small subunit $(\mathrm{RbcS})$, are substituted to further ascertain the possible destabilising effects of multiple section mutations. To that end, combinations of Synechococcus RbcL Sections 1 (residues 1-47), 2 (residues 48-97), 5 (residues 198-247) and 10 (residues 448-472), and RbcS, were swapped with collinear Chlamydomonas sections and expressed in $\mathrm{E}$. coli. Interestingly, only the chimera with Sections 1 and 2 together produces holoenzyme and an interaction network of complementing amino acid changes is delineated by crystal structure analysis. Furthermore, sequence-based analysis also highlighted possible GroEL binding site differences between the two RbcLs.
\end{abstract}

Keywords: Chaperone; Chlamydomonas reinhardtii; protein assembly; ribulose bisphosphate carboxylase/oxygenase (Rubisco); Synechococcus elongatus PCC6301

ABSTRAK

Kajian untuk mengubah suai ribulosa-1,5-bisfosfat karboksilase/oksigenase (Rubisco) bagi memperbaiki proses fotosintesis adalah usaha yang telah lama dijalankan. Subunit- besar Rubisco amat konservatiftetapi disebabkan perbezaan jujukan asid amino yang tertentu, Rubisco tumbuh-tumbuhan tidak dapat dikaji dengan menggunakan sistem pengekspresan Escherichia coli yang serba-boleh serta mekanisme penglipatan GroEL-nya. Sebelum ini, satu siri Rubisco kimerik yang menggabungkan jujukan daripada cyanobacteria Synechococcus elongatus dengan alga hijau Chlamydomonas reinhardtii telah diekspreskan ke dalam E. coli; dalam uji kaji tersebut, perbezaan yang merangkumi seksyen RbcL yang mustahak dalam pembentukan holoenzim telah ditentukan. Dalam uji kaji ini, seksyen lain yang mungkin tidak penting untuk pembentukan holoenzim, bersama-sama subunit kecil ( $\mathrm{RbcS}$ ) telah digantikan untuk menentukan kemungkinan kesan ketidakstabilan akibat mutasi seksyen berbilang. Untuk itu, kombinasi Synechococcus RbcL Seksyen 1 (residu 1-47), 2 (residu 48-97), 5 (residu 198-247) dengan 10 (residu 448-472) dan RbcS, telah digantikan dengan seksyen Chlamydomonas yang kolinear dan diekspreskan dalam E. coli. Kesimpulannya, hanya kimera yang ditukarkan keduadua Seksyen 1 dan 2 dapat membentuk holoenzim dan rangkaian interaksi yang meliputi perubahan asid amino yang saling melengkapkan berdasarkan analisis struktur kristal telah dikemukakan. Selain itu, analisis berasaskan jujukan asid amino juga menunjukkan bahawa perbezaan tapak ikatan GroEL yang mungkin bagi RbcL.

Kata kunci: Chaperone; Chlamydomonas reinhardtii; himpunan protein; ribulosa-1,5-bisfosfat karboksilase/oksigenase (Rubisco); Synechococcus elongatus PCC6301

\section{INTRODUCTION}

Ribulose-1, 5-bisphosphate carboxylase/oxygenase (Rubisco,E.C 4.1.1.39) is responsible for the sustainability of our biosphere, as it is the first enzyme in the Calvin cycle that carries out carbon fixation with the purpose of assimilating atmospheric carbon dioxide into organic molecules for cellular metabolism and biomass accumulation (Andersson \& Backlund 2008; Campbell \& Ogren 1992). Rubisco makes up about half of the total protein composition in C3 leaf cells and approximately one third of the total soluble protein in $\mathrm{C} 4$ leaves, thus hinting at its importance (Ellis 1979; Feller et al. 2008). Different forms of the multi-subunit enzyme have been elucidated, including the hexadecameric form I, the 
dimeric form II, the multi-dimeric form III and the multi-dimeric Rubisco-like form IV (Tabita et al. 2008, 2007a). All these are putatively derived from an ancestral protein in a methanogenic archaeon (Tabita et al. 2007b). Hexadecameric Form I Rubisco has long been the subject of intensive study, due to it being the major form found in higher plants and many microorganisms, with the endgoal often being the successful engineering of a 'better' Rubisco (Andersson \& Backlund 2008; Genkov et al. 2006; Gutteridge et al. 1993; Spreitzer et al. 1995). Form I Rubisco consists of eight large subunits (RbcL), which are arranged as a tetramer of dimers. These are capped by eight small subunits (RbcS) at the top and bottom of the RbcL octamer (Figure 1(A)). Each holoenzyme possesses eight active sites, which are formed by the C-terminal domain of one RbcL and the N-terminal domain of an adjacent RbcL in each dimer (Curmi et al. 1992; Knight et al. 1990; Taylor et al. 2001).

Generally, Rubisco catalyses the carboxylation of ribulose-1,5-bisphosphate (RuBP) with $\mathrm{CO}_{2}$, producing two molecules of 3-phosphoglycerate, which contributes toward photosynthetic growth, but this 'schizophrenic' bifunctional enzyme sometimes catalyses oxygenation of RuBP with $\mathrm{O}_{2}$ (up to a third of the time under atmospheric conditions), producing 2-phosphoglycolate, which has to be metabolized in an unfavourable ATP-consuming $\mathrm{CO}_{2}-$ releasing photorespiratory process (Laing et al. 1974; Ogren 1984; Peterhansel et al. 2008). This difficulty in discriminating between competing substrates $\mathrm{CO}_{2}$ and $\mathrm{O}_{2}$, which is attributed to their electrostatic similarities (Kannappan \& Gready 2008), restricts photosynthetic growth considerably in most plants, leading to losses in biomass yields (Bainbridge et al. 1995; Parry et al. 2007). Indeed, the specious diversity of Rubisco kinetic properties and evolution of $\mathrm{CO}_{2}$-concentrating mechanisms found in particular microalgae, cyanobacteria and higher plants point at shortcomings within the enzyme that are preventing maximum carbon fixation (Chen \& Spreitzer 1992; Meyer et al. 2012; Tcherkez et al. 2006). Oft times a high $\mathrm{CO}_{2} / \mathrm{O}_{2}$ specificity is compromised by a low carboxylation rate and vice versa (Chen \& Spreizer 1992; Tcherkez et al. 2006; Whitney et al. 2011).

The search for a 'better' Rubisco began when kinetic properties of Rubiscos from various photosynthetic organisms were elucidated, with Rubiscos from thermophilic red algae having the highest $\mathrm{CO}_{2} /$ $\mathrm{O}_{2}$ specificity, alongside an acceptable albeit lower carboxylation rate compared to crop species (Jordan \& Ogren 1981; Tcherkez et al. 2006; Whitney et al. 2011). It was calculated that the successful substitution of Rubisco from $\mathrm{C}_{3}$ crop plant with that of the red alga Griffithsia monilis $\left(\mathrm{CO}_{2} / \mathrm{O}_{2}\right.$ specificity factor of 167$)$ can well increase photosynthetic yield by more than 25\% (Long et al. 2006; Zhu et al. 2004). Unfortunately, Rubisco subunits from phylogenetically distant organisms often fail to assemble, which has limited the diversity of Rubisco genes available for genetic engineering.
When the form I Rubiscos of non-green alga Galdieria sulphuraria and diatom Phaeodactylum tricornutum were introduced into tobacco, the holoenzymes could not form, with the possible cause being an incompatible chaperonemediated folding pathway (Whitney et al. 2001). It is only recently that plant Rubiscos were functionally expressed in E. coli by co-expressing their chaperone counterparts (Aigner et al.2017). Mutagenesis and directed evolution studies involving localized changes of the holoenzyme on the other hand yielded mixed results, with the most promising being those involving Rubisco-dependent $E$. coli selection systems whereby there are trade-offs between functional expression and kinetic efficiencies (Mueller-Cajar \& Whitney 2008; Parikh et al. 2006; Smith \& Tabita 2003; Wilson et al. 2017).

Sequence and structure-based approaches to investigate non-formation of the holoenzyme would involve analysing effects of each residue substitution on intra-molecular interactions that affects protein conformation, while also assessing solvent accessibility changes in the RbcL sequence for each progression of the subunit assembly up to the order of the complete holoenzyme (Stan et al. 2006). This is critical as placing hydrophobic residues on solvent-exposed surfaces might lead to protein aggregation while having a polar residue within the hydrophobic core might be destabilizing to the protein structure (Cordes \& Sauer 1999; Pakula \& Sauer 1990). However, there are cases whereby polar residues within the interior of folded proteins contribute greater stability via hydrogen bonding and van der Waals interactions (Pace 2001). In fact, buried polar groups in mutant human lysozymes exact a low-energy cost that is compensated by forming hydrogen bonds to overcome the loss of hydrophobic effects on protein stability (Takano et al. 2001). Furthermore, the number of residue substitutions is also a factor to consider. With Synechococcus and Chlamydomonas RbcLs having a total of 85 residue differences, there should be a limit to the number of substitutions a wild-type Rubisco can tolerate before both function and stability are lost (Bloom et al. 2005; Burger et al. 2006).

In a previous study, an effort was made to determine the RbcL domains of cyanobacteria Rubisco that are essential for successful holoenzyme formation in Escherichia coli (Koay et al. 2016). Sections spanning the whole coding sequence of cyanobacterial $r b c L$ from Synechococcus PCC6301 were swapped sequentially with homologous sections of the eukaryotic $r b c L$ gene from Chlamydomonas reinhardtii to generate ten chimeric mutants. In the end, it was established that four Synechococcus RbcL sections with residues 1-47, 4897, 198-247 and 448-472 could be separately swapped without nullifying holoenzyme formation in E. coli (Koay et al. 2016).

In this follow-up study, we attempt to determine the extent to which Synechococcus RbcL can be phylogenetically substituted to Chlamydomonas RbcL 
and still form holoenzyme in E. coli. To do so, various combinations of Synechoccous RbcL sections involving the aforementioned residues 1-97, 198-247 and 448472 were swapped with their collinear sections in Chlamydomonas RbcL. As it turns out, Synechococcus RbcL can only tolerate the combined swapping of residues 1-47 and 48-97, whereby holoenzyme formation for this mutant is detectable in E. coli lysate via nondenaturing PAGE and immunoblotting, but in a greatly reduced amount. Furthermore, to determine whether changing RbcS to that of Chlamydomonas can structurally complement the amino acid changes in RbcL, a chimeric Synechococcus Rubisco with all four RbcL sections substituted and lacking holoenzyme formation had its RbcS substituted, but that did not restore holoenzyme formation.

\section{MATERIALS AND METHODS}

\section{CHIMERIC SYNECHOCOCCUS RBCL CONSTRUCTION AND CHLAMYDOMONAS RBCS SUBSTITUTION}

Chimeric Rubisco plasmids (Figure 1(B)) were mainly created by using primers and existing plasmids from Koay et al. (2016) to amplify selected fragments, which were then digested with restriction enzymes as indicated in the primer names and then ligated into the pTrcHisB vector backbone of NcoI/PstI-digested pTrcSynLS (MuellerCajar \& Whitney 2008). $\mathrm{pL}^{1+10} \mathrm{~S}$ was constructed by ligating fragments from pTrcSynL(Chl1-50)S (Koay et al. 2016) and pTrcSynL(Chl451-475)S (Koay et al. 2016), which were amplified with primer pairs ChlN-NcoI/Syn150-rev-BsmBI (Koay et al. 2016) and Syn150-fwd-BsmBI/SynSS-C-PstI (Koay et al. 2016), respectively. $\mathrm{pL}^{1+2+5+10} \mathrm{~S}$ had fragments from $\mathrm{pTrcChlLS}$ SynSS (a plasmid with Synechococcus rbcL replaced by Chlamydomonas, unpublished), pTrcSynL(Chl200-250) S (Koay et al. 2016) and pTrcSynL(Chl451-475)S (Koay et al. 2016), which were amplified with primer pairs ChlN-NcoI/Chl100-rev-BsmBI (Koay et al. 2016), Syn100-fwd-BsmBI/Syn400-rev-BsmBI (Koay et al. 2016) and Syn400-fwd-BsmBI/SynSS-C-PstI (Koay et al. 2016), respectively. $\mathrm{pL}^{1+2} \mathrm{~S}$ had fragments from $\mathrm{pL}^{1+2+5+10} \mathrm{~S}$ and pTrcSynLS (Mueller-Cajar \& Whitney 2008), which were amplified with primer pairs ChlNNcoI/Syn150-rev-BsmBI (Koay et al. 2016) and Syn150-fwd-BsmBI/SynSS-C-PstI (Koay et al. 2016), respectively. $\mathrm{pL}^{1+2+10} \mathrm{~S}$ had fragments from $\mathrm{pL}^{1+2+5+10} \mathrm{~S}$ and pTrcSynL(Chl451-475)S (Koay et al. 2016), which were amplified with primer pairs ChlN-NcoI/ Syn150-rev-BsmBI (Koay et al. 2016) and Syn150-fwdBsmBI/SynSS-C-PstI (Koay et al. 2016), respectively. $\mathrm{pL}^{1+2+5+10} \mathrm{~S}^{C}$ had fragments containing chimeric $r b c L$ from $\mathrm{pL}^{1+2+5+10} \mathrm{~S}$ and Chlamydomonas rbcS from $\mathrm{pSS} 1$ ITP (Genkov et al. 2010), which were amplified with primer pairs ChlN-NcoI (Koay et al. 2016)/SynSSNlink-rev-BsmBI (5'-CTTTGGGCAGAGTTCGTCTCCT
CATGATTCAGAAATC-3') and ChlSS-N-fwd-BsmBI (5'-CTCAGGCCGTCTCGATGATGGTCTGGACC-3')/ ChlSS-C-rev-PstI(5'-CTCAGATCGCTGCAGATCTCG ACTTACACGGAGCGCTTG-3'). Constructed plasmids were electroporated into $E$. coli $\mathrm{XL}-1$ Blue, which were then selected at $37^{\circ} \mathrm{C}$ overnight on LB plates with $200 \mu \mathrm{g} / \mathrm{mL}$ ampicillin. Plasmids were verified by size screening on an agarose gel, restriction enzyme mapping and sequencing of the bicistronic $r b c L-r b c S$ operon.

\section{PROTEIN EXPRESSION AND ASSEMBLY ANALYSES OF CHIMERIC RUBISCOS}

Essentially, Rubisco expression and protein analyses were carried out similar to Koay et al. (2016). Briefly, XL-1 Blue E. coli were electroporated with the verified $r b c L$ $r b c S$ constructs and selected on $200 \mu \mathrm{g} / \mathrm{mL}$ ampicillin LB plates at $37^{\circ} \mathrm{C}$ to obtain single colonies, which were picked and grown overnight at $37^{\circ} \mathrm{C}$ in $10 \mathrm{mLLB}$ cultures (100 $\mu \mathrm{g} / \mathrm{mL}$ ampicillin). These starter cultures were then transferred to fresh $100 \mu \mathrm{g} / \mathrm{mL}$ ampicillin LB broths and grown to $\mathrm{OD}_{600}$ of 0.5 at $37^{\circ} \mathrm{C}$. Rubisco expression was induced with $0.5 \mathrm{mM}$ IPTG for $16 \mathrm{~h}$, after which, E. coli cells were harvested, resuspended to $10 \%(\mathrm{w} / \mathrm{v})$ in icecold extraction buffer (50 mM Bicine-NaOH, pH8.0, 10 $\mathrm{mM} \mathrm{MgCl}, 10 \mathrm{mM} \mathrm{NaHCO}_{3}, 2 \mathrm{mM}$ DTT) and sonicated. Following that, total cellular proteins were resolved on $7.5 \%$ native-PAGE gel, or denatured by mixing with SDS-containing loading buffer and boiled for $30 \mathrm{~min}$ before resolving on $12 \%$ SDS-PAGE gels. For Western blotting, resolved proteins were probed using rabbit anti-Synechococcus PCC6301 Rubisco IgG (Parikh et al. 2006) and for the detection of Chlamydomonas RbcS in SDS-PAGE, additional rabbit anti-Chlamydomonas $\mathrm{RbcS}$ IgG (Esquivel et al. 2013) was used.

\section{SCANNING OF CHLAMYDOMONAS AND SYNECHOCOCCUS RBCL SEQUENCES FOR GROEL-BINDING MOTIFS AND HYDROPHOBIC PATCHES}

GroEL substrate-protein binding motifs are postulated to have amino acid functional groups characteristic of the GroES mobile loop, which binds in the hydrophobic groove formed by two helices of the GroEL apical domain (Stan et al. 2004). The most elementary motif is P_HHH, whereby ' $P$ ' refers to (p)olar amino acids Asn, Gln, Gly, His, Pro, Ser and Thr, '- ' refers to any of the twenty amino acids, and ' $\mathrm{H}$ ' refers to (h)ydrophobic amino acids Ala, Cys, Ile, Leu, Met, Phe, Trp, Tyr and Val (Stan et al. 2006). A further criterion applied in the search for binding motifs is that these residues should become inaccessible upon transition to the native assembled Rubisco oligomer (Stan et al. 2006).

A second approach to look for GroEL recognition sites was by screening Synechococcus and Chlamydomonas $\mathrm{RbcL}$ for local hydrophobic patches with average hydropathy indices (Kyte \& Doolittle 1982) greater or similar to that of the GroEL-binding seven-residue GroES mobile loop region, which has amino acid identity GGIVLTG 
and hydropathy index of 1.514 (Chaudhuri \& Gupta 2005; Kumar et al. 2012).

\section{RESULTS}

STRUCTURAL POSITION OF THE SWAPPED LARGE SUBUNIT SECTIONS AND CONSTRUCTS OF CHIMERIC RUBISCOS

Residues changed in Rubisco large subunit Sections 1, 2 and 10 are mainly situated on the holoenzyme surface (Figure 1(A)). In addition, because Sections 1 and 10 are at the $\mathrm{N}$ - and $\mathrm{C}$-terminal ends of the large subunit, respectively, these sections were predicted to be flexible and more tolerable of amino acid changes, therefore, a chimeric Synechococcus Rubisco was created with these two terminal end sections swapped to Chlamydomonas while retaining the Synechococcus small subunit $\left(\mathrm{L}^{1+10} \mathrm{~S}\right.$ in Figure 1(B)). Next, because Sections 1 and 2 are adjacent in the protein primary structure and comprise over $60 \%$ of the 150 -amino acid ferredoxin-like fold $\mathrm{N}$-terminal domain, these sections were predicted to have complementing residue interactions that might warrant changing the interacting functional groups simultaneously, therefore, a chimeric Synechococcus Rubisco was made with only these two sections substituted with that of Chlamydomonas $\left(\mathrm{L}^{1+2} \mathrm{~S}\right.$ in Figure $\left.1(\mathrm{~B})\right)$. A chimera was also constructed replacing mainly the surface sections (Sections 1, 2 and 10) $\left(\mathrm{L}^{1+2+10} \mathrm{~S}\right.$ in Figure $\left.1(\mathrm{~B})\right)$ since perturbations on the holoenzyme surface is predicted to be less destabilizing to its structural core. Another chimera was also created with all four sections (Sections 1,2, 5 and 10) substituted $\left(\mathrm{L}^{1+2+5+10} \mathrm{~S}\right.$ in Figure $\left.1(\mathrm{~B})\right)$ followed by a further chimera, which had the Chlamydomonas Rubisco small subunit $\left(\mathrm{L}^{1+2+5+10} \mathrm{~S}^{C}\right.$ in Figure $\left.1(\mathrm{~B})\right)$ to ascertain whether accompanying small subunit changes can complement large subunit alterations caused by our sectional swaps.

\section{PROTEIN EXPRESSION}

For all chimeric Rubisco constructs, the mutant genes were expressed in E. coli, with the RbcL and RbcS proteins detected in each transformant cell lysate when resolved by

\section{A}
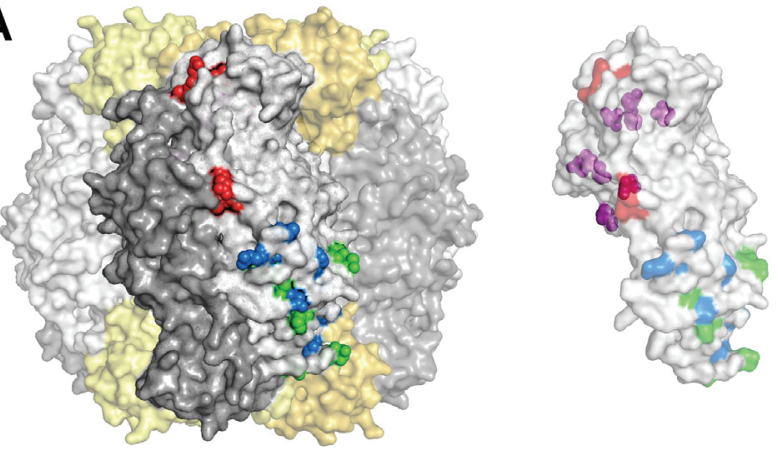

B Chlamydomonas rbcL

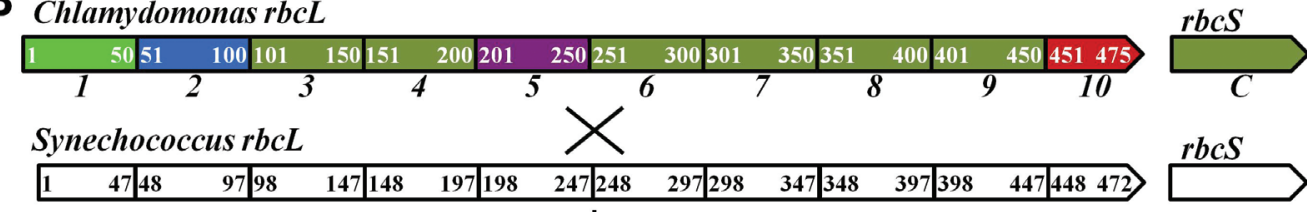

\begin{tabular}{llllllllllll}
\hline & & & \\
\hline
\end{tabular}

FIGURE 1. A) Location of amino acids mutated in the holoenzyme of Synechococcus Rubisco (PDB ID 1RBL). Left, complete hexadecameric holoenzyme with large subunits in silver and white and small subunits in gold and yellow. Mutated residues are indicated (green, Section 1; blue, Section 2; purple, Section 5; red, Section 10) for only one subunit. Right, a single subunit is shown as transparent surface with Section 5 residues as solid spheres (purple) and B) constructs of the chimeric Rubiscos with section numbers denoted below the Chlamydomonas genes. Amino acid numbers are demarcated in each section, in lieu of base pairs 
SDS-polyacrylamide gel electrophoresis, blotted and probed with anti-Rubisco antibodies (Figure 2). RbcL levels only differed slightly among the various Rubisco transformants based on SDS-PAGE, albeit these differences become seemingly striking upon immunoblotting, most likely because of alterations to the epitope identity and antibody affinity in some of the mutants as a result of changing their protein sequences (Figure 2). However, for reasons that have yet to be ascertained, RbcS levels were lower for cells with the mutant constructs compared to the one with the wild-type construct (Figure 2), but because the $r b c L$ and $r b c S$ genes were expressed as a bicistronic transcript, it is reasonable to eliminate disparate transcript stabilities and levels as a cause for the reduced $\mathrm{RbcS}$ production.

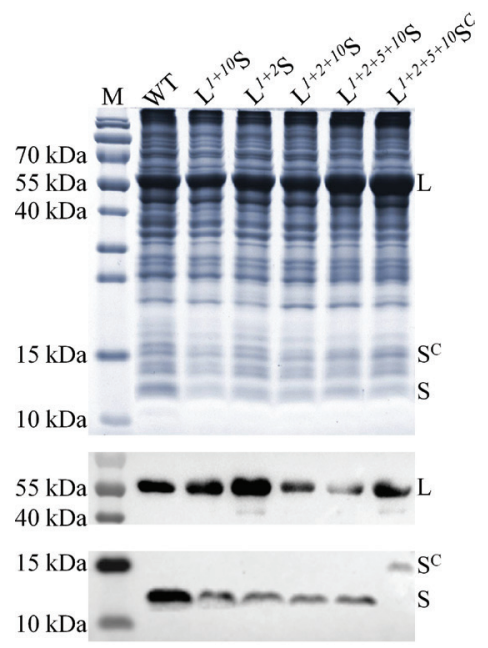

FIGURE 2. SDS-PAGE (top) and Western blot (middle and bottom) analyses of total cellular protein from $E$. coli expressing Synechococcus Rubisco (WT) or the various chimeric mutants. Protein marker $(\mathrm{M})$ with band sizes (in $\mathrm{kDa}$ ) labelled was run concurrently. Synechococcus large (L) and small (S) subunits and

Chlamydomonas small subunit $\left(\mathrm{S}^{C}\right)$ are indicated

\section{PROTEIN ASSEMBLY}

Remarkably, only the chimeric Rubisco with RbcL sections 1 and 2 swapped $\left(\mathrm{L}^{1+2} \mathrm{~S}\right)$ formed complete hexadecameric holoenzyme at a detectable level on native-polyacrylamide gel and immunoblotting, though the amount of assembled holoenzyme is markedly less than that of wild type (Figure 3). The absence of other chimeric holoenzymes and the reduced amount of $\mathrm{L}^{1+2} \mathrm{~S}$ suggested that the various mutations are destabilizing and combining these mutations abrogates holoenzyme formation. Perhaps other complementing amino acid substitutions in RbcL sections that were not probed in the current study are required.

\section{BIOINFORMATICS ANALYSES}

GroEL binding motifs were found throughout RbcL, specifically in Sections 1, 2, 3, 4, 6, 9 and 10 (Supplementary File 1). When considering only binding motifs that are buried in the native hexadecameric Rubisco, Chlamydomonas RbcL has twelve putative GroEL binding motifs whereas Synechococcus RbcL only has nine (Table 1). The three additional motifs in Chlamydomonas RbcL are in Sections 6 and 9 (Table 1). Because binding motifs need to be ten residues apart on the primary structure in order to bind to adjacent GroEL subunits (Stan et al. 2004), the three additional motifs possibly extend the Sections 6 and 9 motifs to encompass extra contact sites with Chlamydomonas chaperones but distort the proper contacts with bacterial chaperones. Conversely, Synechococcus RbcL has twenty eight hydrophobic patches with hydropathy indices greater than that of the GroES mobile loop, which is the best GroEL substrate, whereas Chlamydomonas RbcL only has sixteen (Supplementary File 2). These seven-residue hydrophobic patches could also hint at binding sites for GroEL. The fourteen additional patches in Synechococcus span Sections 2 (into 3), 3, 4,

TABLE 1. Substrate protein binding motifs in RbcLs that are buried in the native state

\begin{tabular}{|c|c|c|c|}
\hline Section & Residue range & Synechococcus Sequence & Chlamydomonas Sequence \\
\hline 1 & $31-35$ & TDLLA & TDILA \\
\hline \multirow{3}{*}{2} & $51-55$ & GAAIA & GAAVA \\
\hline & $92-96$ & NSYFA & NQYIA \\
\hline & $93-97$ & SYFAF & QYIAY \\
\hline 3 & $138-142$ & PVALV & PPAYV \\
\hline 4 & $183-187$ & GRAVY & GRAVY \\
\hline \multirow{3}{*}{6} & $275-279$ & TTLAK & TSLAI \\
\hline & $276-280$ & TLAKW & SLAIY \\
\hline & $284-288$ & NGVLL & NGLLL \\
\hline \multirow{2}{*}{9} & $412-416$ & PGATA & PGAAA \\
\hline & $417-421$ & NRVAL & NRVAL \\
\hline 10 & $450-454$ & PELAA & PELAA \\
\hline
\end{tabular}

Residue numbering is based on Synechococcus RbcL. Binding motifs are bolded 
6, 7, 8 and 9, while the two additional Chlamydomonas patches are in Sections 4 and 6 (Table 2). Notwithstanding the disparity in the number of GroEL binding sites found, both sequence-based methods in this study mainly preclude sites from Sections 1, 2, 5, and 10.

\section{DISCUSSION}

Here we show that when Synechococcus PCC6301 RbcL sections previously defined as non-determinants for holoenzyme formation (Koay et al. 2016) were simultaneously swapped with that of Chlamydomonas, the various mutant combinations mainly resulted in additive effects that nullified holoenzyme production. Only the chimeric Rubisco having RbcL Sections 1 and 2 substituted together, totalling 25 residue substitutions, could form in the E. coli transformants, albeit at reduced levels compared to wild-type Rubisco (Figure 3). This implies that even though Sections 1 (residues 1-47), 2 (residues 48-97), 5 (residues 198-247) and 10 (residues 448-472) of Synechococcus RbcL may be separately non-critical for holoenzyme assembly, they do contain residues that provide a certain stability to the overall protein conformation.

The structural basis for why residue changes in the aforementioned sections influence holoenzyme stability can be deduced by comparing the Rubisco structures of Chlamydomonas (PDB ID 1GK8) and Synechococcus (PDB ID 1RBL). The large subunit $\mathrm{N}$-terminus has a different conformation between Synechococcus and
Chlamydomonas (Figure 4). Because substitutions in this region comprise of S9A and A10G (Chlamydomonas RbcL numbering) occur in Section 1 chimeras, which includes all chimeric proteins in this study, the chimeric large subunits are predicted to mimic the Chlamydomonas $\mathrm{N}$-terminus structural arrangement, which could cause losses of van der

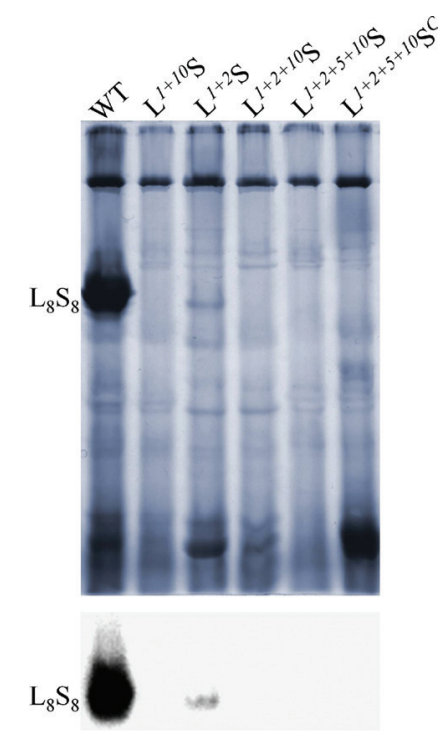

FIGURE 3. Native-PAGE (top) and Western blot (bottom) analyses of total cellular protein from E. coli expressing Synechococcus Rubisco (WT) or the various chimeric mutants. Assembled hexadecameric holoenzyme $\left(\mathrm{L}_{8} \mathrm{~S}_{8}\right)$ is indicated

TABLE 2. Sequences with hydropathicities higher than the GroES mobile loop (1.514) and are present in either only Synechococcus or Chlamydomonas RbcL

\begin{tabular}{|c|c|c|c|c|c|}
\hline \multirow{2}{*}{ Section } & \multirow{2}{*}{ Residue range } & \multicolumn{2}{|c|}{ Synechococcus } & \multicolumn{2}{|c|}{ Chlamydomonas } \\
\hline & & Sequence & Hydropathy index & Sequence & Hydropathy index \\
\hline \multirow{4}{*}{$2 / 3$} & 93-99 & SYFAFIA & 1.6571 & QYIAYVA & 0.8857 \\
\hline & $94-100$ & YFAFIAY & 1.5857 & YIAYVAY & 1.2000 \\
\hline & $95-101$ & FAFIAYP & 1.5429 & IAYVAYP & 1.1571 \\
\hline & 96-102 & AFIAYPL & 1.6857 & AYVAYPI & 1.1571 \\
\hline \multirow{5}{*}{3} & $112-118$ & NILTSIV & 1.7143 & NMFTSIV & 1.2000 \\
\hline & $135-141$ & IRFPVAL & 1.5714 & LRIPPAY & 0.1571 \\
\hline & $136-142$ & RFPVALV & 1.5286 & RIPPAYV & 0.2143 \\
\hline & $137-143$ & FPVALVK & 1.6143 & IPPAYVK & 0.3000 \\
\hline & $139-145$ & VALVKTF & 1.7429 & PAYVKTF & 0.1857 \\
\hline 4 & $165-171$ & PMLGCTI & 1.4286 & GLLGCTI & 1.8714 \\
\hline \multirow{2}{*}{6} & $256-262$ & ELGMPII & 1.3143 & ELGVPII & 1.6429 \\
\hline & $261-267$ & IIMHDFL & 1.5429 & IIMHDYL & 0.9571 \\
\hline 7 & $337-343$ & ASTLGFV & 1.5286 & EVTLGFV & 1.4857 \\
\hline \multirow{2}{*}{8} & $370-376$ & GVLPVAS & 1.6000 & GVMPVAS & 1.3286 \\
\hline & $371-377$ & VLPVASG & 1.6000 & VMPVASG & 1.3286 \\
\hline 9 & $419-425$ & VALEACV & 2.1143 & VALEACT & 1.4143 \\
\hline
\end{tabular}

Residue numbering is based on Synechococcus RbcL. Sequences with hydropathy indices greater than 1.514 are bolded 
Waals contacts between the large subunit residues and the Synechococcus small subunit residues His-39 in $\beta$-strand $A$ and Phe-63 in the loop between $\beta$-strand B and $\alpha$-helix B (Figure 4). A previous alanine-scanning mutagenesis study on Chlamydomonas small subunit demonstrated compelling evidence that $\beta$-strand $\mathrm{A}$ has a role in holoenzyme stability, whereby an E43A mutant enzyme was unstable at an elevated temperature of $35^{\circ} \mathrm{C}$ (Genkov \& Spreitzer 2009). An F81A (Phe-63 in Synechococcus) mutant Chlamydomonas enzyme also had a decrease in thermal stability (Genkov \& Spreitzer 2009). Therefore, it is unsurprising that our mutant chimeras with alterations that potentially disrupt complementing residue interactions between the large subunit $\mathrm{N}$-terminus and small subunit have impaired protein stability. To test whether these disruptions can be restored by concomitant changes to the small subunit, we also constructed a chimeric enzyme with the small subunit swapped, but curiously, assembled holoenzyme still could not form (Figure 3).

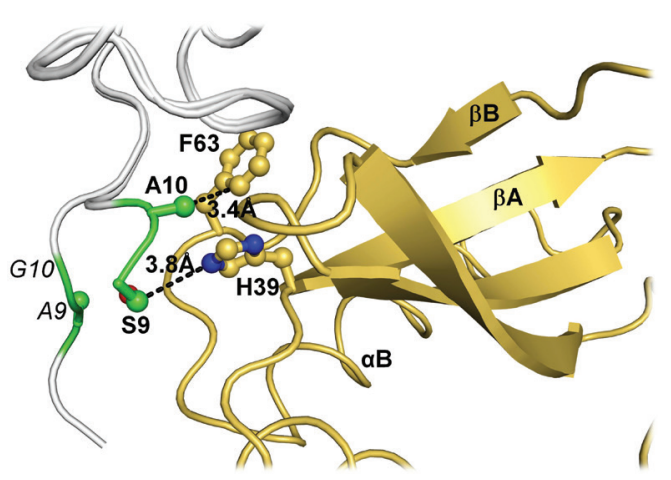

FIGURE 4. Overlaid Synechococcus (PDB ID 1RBL) and Chlamydomonas (PDB ID 1GK8) large subunits (white ribbons), with differing crucial N-terminus Section 1 residues (green) which interacts with the Synechococcus small subunit (gold). Critical residues are represented with ball and sticks (blue, nitrogen; red, oxygen) and bolded (Synechococcus) or italicised (Chlamydomonas). Large subunit residues are numbered based on the Chlamydomonas sequence. Measured distances (in $\AA$ ) for large/small subunit contacts which are lost upon mutation are indicated

In addition to Section 1, changes in other sections are also predicted to perturb amino acid side-chain interactions. Large subunit Leu-73 (Chlamydomonas RbcL numbering), which is mutated to Gly-73 in the Section 2 chimeras, is expected to have weakened, if not lost van der Waals contacts between the significantly diminished glycine functional group and the large subunit N-terminus (Figure 5). Another Section 2 mutation, K83R (Chlamydomonas RbcL numbering) on $\beta$-strand $C$ potentially lengthens the distance between residue 83 and the pyrrole ring of Pro104 , which is positioned between $\beta$-strand $\mathrm{D}$ and $\alpha$-helix C (Figure 6). Interestingly, Pro-104 is hydroxylated in the Chlamydomonas enzyme, albeit replacement of this residue with alanine did not cause any obvious structural disruptions despite its close proximity to the interface between interdimeric large subunits (Rasineni et al. 2017). Within the Section 2 chimeras, $\beta$-strand $C$ also has a H86D (Chlamydomonas RbcL numbering) mutation, which might cause destabilizing repulsive forces with the similarly negatively-charged Glu-88 on the same secondary structural element (Figure 6). Indeed, our results accord with a previous study whereby several mutations on $\beta$-strand C, including D86R and P89A, halved the amount of holoenzymes produced relative to wild type (Ott et al. 2000).

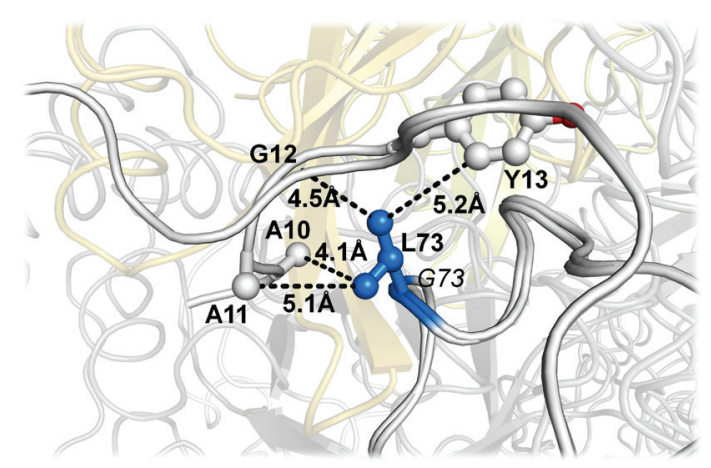

FIGURE 5. Comparison of residue 73 (blue) interactions in aligned large subunits (white ribbons) of Synechococcus (PDB ID 1RBL) and Chlamydomonas (PDB ID 1GK8). Distances (in $\AA$ ) for contacts with N-terminus residues (represented with white ball and sticks; oxygen atom is red) that might be lost in the Section 2 mutants are denoted. Large subunit residues are numbered based on the Chlamydomonas sequence. Synechococcus residues are in bold whereas Chlamydomonas are in italics

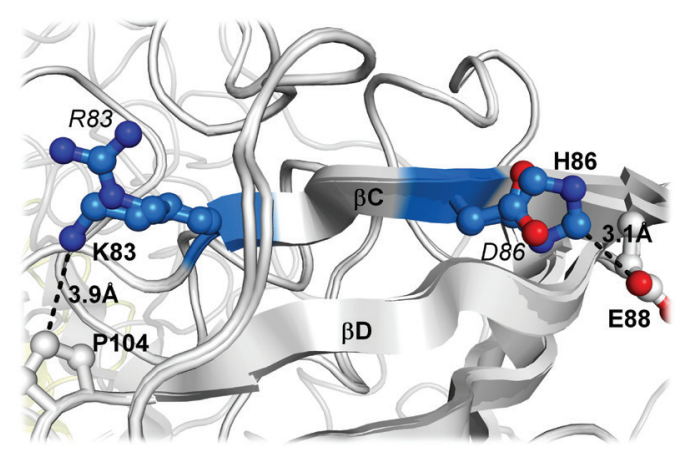

FIGURE 6. Differences in $\beta \mathrm{C}$ residues (light blue; nitrogen atoms are dark blue; oxygen atoms are red) between aligned large subunits (white) of Synechococcus (PDB ID 1RBL) in bold and Chlamydomonas (PDB ID 1GK8) in italics. Contacts with neighbouring residue (represented with white ball and sticks; oxygen atoms, red) that might be lost in the Section 2 mutants are measured (in $\AA$ ). Large subunit residues are numbered based on the Chlamydomonas sequence

For Section 10 chimeras, as a consequence of amino acid substitution L459C, abolished van der Waals contact between the branched isobutyl side chains of Leu-459 on large subunit $\alpha$-helix $H$ and Leu- 445 on $\alpha$-helix $G$ is 
proposed (Chlamydomonas numbering for all residues) (Figure 7). In Chlamydomonas Rubisco, Cys-459 is disulfide bonded to Cys-449 whereby site-directed mutagenesis showed a noticeable structural instability to the holoenzyme upon disruption of this covalent bond (Marin-Navarro \& Moreno 2006). Because the Section 10 chimeras have Gly-449 instead, the remaining unpaired Cys-459 still renders the enzyme susceptible to redox modulation which intensifies the proteolytic degradation of the enzyme (Marin-Navarro \& Moreno 2006).

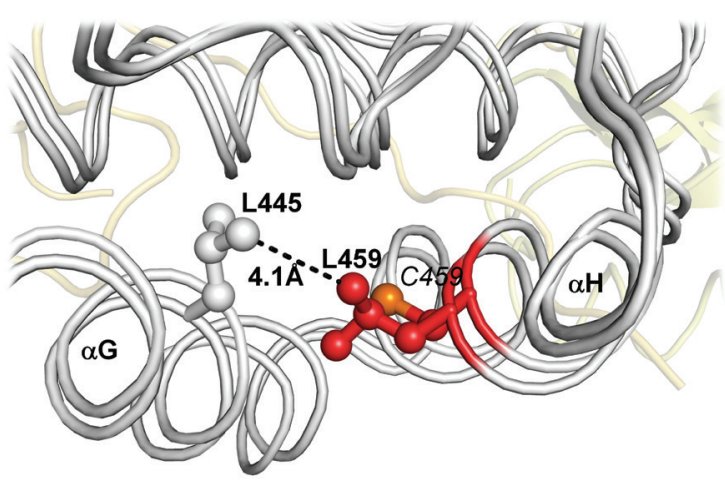

FIGURE 7. Comparison of residue 459 (red) in aligned large subunits (white ribbons) of Synechococcus (PDB ID 1RBL) (in bold) and Chlamydomonas (PDB ID 1GK8) (in italics). Contact with Leu-445 (white ball and sticks), which is denoted in $\AA$, might be lost in the Section 10 mutants. Large subunit residues are numbered based on the Chlamydomonas sequence

One could attempt to deduce whether a particular mutant protein would successfully form holoenzyme or not based on mutational strain threshold by simply counting the number of amino acid changes since protein instability generally increases with mutations (Bloom et al. 2005). However, such an approach would miss the mark in this case because while Chimera $\mathrm{L}^{1+2} \mathrm{~S}$, which has as many as 25 residue substitutions encompassing Sections 1 and 2, is capable of holoenzyme formation, Chimera $\mathrm{L}^{1+10} \mathrm{~S}$, which has only 18 substitutions, could not produce assembled holoenzyme (Figure 3). Therefore, we infer that there must be some thermodynamically favourable complementary bond or interaction that is engendered between Sections 1 and 2 when both sections assumed the Chlamydomonas identity. Indeed, upon closer inspection of the crystal structures, there is a network of interaction between Chlamydomonas large subunit residues Arg-21 (Lys-21 in Synechococcus) to Glu-51 (Asp-51 in Synechococcus) and Pro-50 (Ala-50 in Synechococcus), which is absent in the Synechococcus structure (Figure 8). These interactive forces may be responsible for stabilizing the folded large subunit.

It is noteworthy that expression of mutant Rubisco large subunits is almost indistinguishable from wild-type in the E. coli transformants despite extensive modifications to the protein sequence (Figure 2). This suggests that transcription and translation of the mutant large subunits are unaffected even though the large subunit has an autoregulatory role in translational arrest by binding to its own mRNA transcript (Cohen et al. 2006; Wostrikoff \& Stern 2007).

In this study, sequence-based approaches were also undertaken to rule out Sections 1, 2, 5 and 10 from harbouring crucial differences in binding sites for the GroEL chaperone which could be key determinants for enabling bacterial Rubisco assembly in E. coli (Goloubinoff et al. 1989; Lin \& Rye 2006; Saschenbrecker et al. 2007) while preventing assembly of eukaryotic Rubisco (Cloney et al. 1993; Koay et al. 2016). Scanning the primary structures of Synechococcus and Chlamydomonas RbcL identified putative GroEL substrate-protein binding motifs (Stan et al. 2006, 2004) in Sections 1, 2, 3, 4, 6 and 9 of the large subunit, with distinctions between the two species limited to Sections 1, 6 and 9, which correspond to Synechococcus residues 1-47, 248-297 and 398-447 (Supplementary File 1). Binding motifs should also be buried when the substrate protein is already in its properly-folded assembled native conformation to avoid unnecessary binding and refolding of it by the chaperone complex (Stan et al. 2006). With this additional criterion, we further narrowed down the possible important binding motifs to within Sections 6 and 9 (Table 1).

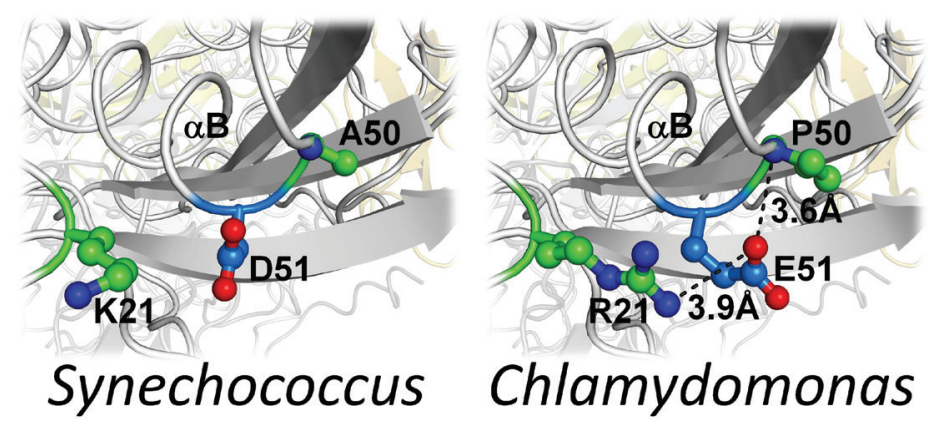

FIGURE 8. Comparison between Synechococcus (PDB ID 1RBL) and Chlamydomonas (PDB ID 1GK8) of critical Sections 1 (green; nitrogen atoms in blue) and 2 (blue; oxygen atoms in red) residues. These residues form a network of interactions in Chlamydomonas, with contact distances shown in $\AA$ 
Another bioinformatics approach is to evaluate the RbcL sequence for seven-residue hydrophobic segments that closely match the hydrophobicity of the seven-residue GroES mobile loop with sequence GGIVLTG, which presents hydrophobic interactions with the GroEL apical domain (Chaudhuri \& Gupta 2005). The GroES loop has a hydropathy index of 1.514 (Chaudhuri \& Gupta 2005), thus hydrophobic patches with hydropathicity greater than 1.514 were evaluated (Table 2). From this analysis, differences in potential GroEL binding sites between Synechococcus and Chlamydomonas are found in Sections 2, 3, 4, 6, 7, 8 and 9 (Table 2). For Section 2 sites, they extend into Section 3 , therefore, the demarcation of Sections 2 and 3 are less well-defined for these sites (Table 2). Hence, distinctions in definable possible GroEL-binding sites between the two species are confined to Sections 3, 4, 6, 7, 8 and 9, which correspond to Synechococcus residues 98-147, 148-197, 248-297, 298-347, 348-397 and 398-447.

From this study, protein assembly analysis of combinatorial mutations indicates that mutations in Sections 1,2,5 and 10 are destabilizing to the holoenzyme but there are possible complementary interactions between Sections 1 and 2, which could partially offset the destabilizing forces. A correlation between the present bioinformatics analyses and chimeric Rubisco holoenzyme formation in Koay et al. (2016) is observed, whereby key determinants for successful Synechococcus, but not Chlamydomonas Rubisco formation in E. coli can be discounted from Sections 1, 2, 5 and 10 of RbcL. The two bioinformatics methods (Chaudhuri \& Gupta 2005; Stan et al. 2006) also concur and seemingly suggest that Sections 6 and 9 could be future targets for investigating disparities between Chlamydomonas and Synechococcus Rubisco formation in E. coli.

\section{ACKNOWLEDGEMENTS}

We are grateful to Dr. Oliver Martin Mueller-Cajar from Nanyang Technology University, Singapore for providing the Synechococcus PCC6301 Rubisco construct pTrcSynLS. We also thank Professor F. Robert Tabita, Ohio State University, for his generosity in providing us with anti-Synechococcus PCC6301 Rubisco antibodies. Special thanks is due to Professor Robert J. Spreitzer of University of Nebraska-Lincoln in providing us with anti-Chlamydomonas Rubisco antibodies and the Chlamydomonas small subunit construct pSS1-ITP. This work was supported by Universiti Tunku Abdul Rahman Research Fund (6200/L87 and 6200/L14).

\section{REFERENCES}

Aigner, H., Wilson, R.H., Bracher, A. Calisse, L., Bhat, J.Y., Hartl,F.U. \& Hayer-Hartl, M. 2017. Plant RuBisCo assembly in E. coli with five chloroplast chaperones including BSD2. Science 358: 1272-1278.

Andersson, I. \& Backlund, A. 2008. Structure and function of Rubisco. Plant Physiology and Biochemistry 46: 275-291.
Bainbridge, G., Madgwick, P.J., Parmar, S., Mitchell, R., Paul, M., Pitts, J., Keys, A.J. \& Parry, M.A.J. 1995. Engineering Rubisco to change its catalytic properties. Journal of Experimental Botany 46: 1269-1276.

Bloom, J.D., Silberg, J.J., Wilke, C.O., Drummond, D.A., Adami, C. \& Arnold, F.H. 2005. Thermodynamic prediction of protein neutrality. Proceedings of the National Academy of Science of the United States of America 102: 606-611.

Burger, R., Willensdorfer, M. \& Nowak, M.A. 2006. Why are phenotypic mutation rates much higher than genotypic mutation rates? Genetics 172: 197-206.

Campbell, W.J. \& Ogren, W.L. 1992. Light activation of Rubisco by Rubisco activase and thylakoid membranes. Plant Cell Physiology 33: 751-756.

Chaudhuri, T.K. \& Gupta, P. 2005. Factors governing the substrate recognition by GroEL chaperone: A sequence correlation approach. Cell Stress Chaperones 10: 24-36.

Chen, Z. \& Spreitzer, R.J. 1992. How various factors influence the $\mathrm{CO}_{2} / \mathrm{O}_{2}$ specificity of ribulose-1,5-bisphosphate carboxylase/ oxygenase. Photosynthesis Research 31: 157-164.

Cloney, L.P., Bekkaoui, D.R. \& Hemmingsen, S.M. 1993. Coexpression of plastid chaperonin genes and a synthetic plant Rubisco operon in Escherichia coli. Plant Molecular Biology 23: $1285-1290$.

Cohen, I., Sapir, Y. \& Shapira, M. 2006. A conserved mechanism controls translation of Rubisco large subunit in different photosynthetic organisms. Plant Physiology 141: 1089-1097.

Cordes, M.H. \& Sauer, R.T. 1999. Tolerance of a protein to multiple polar-to-hydrophobic surface substitutions. Protein Science 8: 318-325.

Curmi, P.M.G., Cascio, D., Sweet, R.M., Eisenberg, D. \& Schreuder, H. 1992. Crystal structure of the unactivated form of ribulose- 1,5-bisphosphate carboxylase/ oxygenase from tobacco refined at 20- $\AA$ resolution. Journal of Biological Chemistry 267: 16980-16989.

Ellis, R.J. 1979. The most abundant protein in the world. Trends in Biochemical Science 4: 241-244.

Esquivel, M.G., Genkov, T., Nogueira, A.S., Salvucci, M.E. \& Spreitzer, R.J. 2013. Substitutions at the opening of the Rubisco central solvent channel affect holoenzyme stability and $\mathrm{CO}_{2} / \mathrm{O}_{2}$ specificity but not activation by Rubisco activase. Photosynthesis Research 118: 209-218.

Feller, U., Anders, I. \& Mae, T. 2008. Rubiscolytics: Fate of Rubisco after its enzymatic function in a cell is terminated. Journal of Experimental Botany 59: 1615-1624.

Genkov, T., Du, Y.C. \& Spreitzer, R.J. 2006. Small subunit cysteine- 65 substitutions can suppress or induce alterations in the large-subunit catalytic efficiency and holoenzyme thermal stability of ribulose-1,5-bisphosphate carboxylase/oxygenase. Archives of Biochemistry and Biophysics 451: 167-174.

Genkov, T. \& Spreitzer, R.J. 2009. Highly conserved small subunit residues influence Rubisco large subunit catalysis. Journal of Biological Chemistry 284: 30105-30112.

Genkov, T., Meyer, M., Griffiths, H. \& Spreitzer, R.J. 2010. Functional hybrid Rubisco enzymes with plant small subunits and algal large subunits: Engineered rbcS cDNA for expression in Chlamydomonas. Journal of Biological Chemistry 285: 19833-19841.

Goloubinoff, P., Gatenby, A.A. \& Lorimer, G.H. 1989. GroE heat-shock proteins promote assembly of foreign prokaryotic ribulose bisphosphate carboxylase oligomers in Escherichia coli. Nature 337: 44-47. 
Gutteridge, S., Rhoades, D.F. \& Herrmann, C. 1993. Site-specific mutations in a loop region of the $\mathrm{C}$-terminal domain of the large subunit of ribulose bisphosphate carboxylase/oxygenase that influence substrate partitioning. Journal of Biological Chemistry 268: 7818-7824.

Jordan, D.B. \& Ogren, W.L. 1981. Species variation in the specificity of ribulose biphosphate carboxylase/oxygenase. Nature 291: 513-515.

Kannappan, B. \& Gready, J.E. 2008. Redefinition of Rubisco carboxylase reaction reveals origin of water for hydration and new roles for active-site residues. Journal of the American Chemical Society 130: 15063-15080.

Knight, S., Andersson, I. \& Brändén, C.I. 1990. Crystallographic analysis of ribulose 1,5-bisphosphate carboxylase from spinach at $2 \cdot 4 \AA$ resolution. Journal of Molecular Biology 215: $113-160$.

Koay, T.W., Wong, H.L. \& Lim, B.H. 2016. Engineering of chimeric eukaryotic/bacterial Rubisco large subunits in Escherichia coli. Genes \& Genetic Systems 91: 139-150.

Kumar, V., Punetha, A., Sundar, D. \& Chaudhuri, T.K. 2012. In silico engineering of aggregation-prone recombinant proteins for substrate recognition by the chaperonin GroEL. BMC Genomics 13: S22.

Kyte, J. \& Doolittle, R.F. 1982. A simple method for displaying the hydropathic character of a protein. Journal of Molecular Biology 157: 105-132.

Laing, W.A., Ogren, W.L. \& Hageman, R.H. 1974. Regulation of soybean net photosynthetic $\mathrm{CO}_{2}$ fixation by the interaction of $\mathrm{CO}_{2}, \mathrm{O}_{2}$, and ribulose 1,5-diphosphate carboxylase. Plant Physiology 54: 678-685.

Lin, Z. \& Rye, H.S. 2006. GroEL-mediated protein folding: Making the impossible, possible. Critical Reviews in Biochemistry and Molecular Biology 41: 211-239.

Long, S.P., Zhu, X-G., Naidu, S.L. \& Ort, D.R. 2006. Can improvement in photosynthesis increase crop yields? Plant, Cell and Environment 29: 315-330.

Marin-Navarro, J. \& Moreno, J. 2006. Cysteines 449 and 459 modulate the reduction-oxidation conformational changes of ribulose 1.5-bisphosphate carboxylase/oxygenase and the translocation of the enzyme to membranes during stress. Plant, Cell and Environment 29: 898-908.

Meyer, M.T., Genkov, T., Skepper, J.N., Jouhet, J., Mitchell, M.C., Spreitzer, R.J. \& Griffiths, H. 2012. Rubisco small-subunit $\alpha$-helices control pyrenoid formation in Chlamydomonas. Proceedings of the National Academy of Science of the United States of America 109: 19474-19479.

Mueller-Cajar, O. \& Whitney, S.M. 2008. Evolving improved Synechococcus Rubisco functional expression in Escherichia coli. Biochemical Journal 414: 205-214.

Ogren, W.L. 1984. Photorespiration: Pathways, regulation, and modification. Annual Review of Plant Physiology and Plant Molecular Biology 35: 415-442.

Ott, C.M., Smith, B.D., Portis, A.R. \& Spreitzer, R.J. 2000. Activase region on chloroplast ribulose-1,5-bisphosphate carboxylase/oxygenase. Journal of Biological Chemistry 275: 26241-26244.

Pace, C.N. 2001. Polar group burial contributes more to protein stability than nonpolar group burial. Biochemistry 40: $310-$ 313.

Pakula, A.A. \& Sauer, R.T. 1990. Reverse hydrophobic effects relieved by amino-acid substitutions at a protein surface. Nature 344: 363-364.
Parikh, M.R., Greene, D.A., Woods, K.K. \& Matsumura, I. 2006. Directed evolution of RuBisCO hypermorphs through genetic selection in engineered E. coli. Protein Engineering, Design and Selection 19: 113-119.

Parry, M.A.J., Madgwick, P.J., Carvalho, J.F.C. \& Andralojc, P.J. 2007. Prospects for increasing photosynthesis by overcoming the limitations of Rubisco. Journal of Agricultural Science 145: 31-43.

Peterhansel, C., Niessen, M. \& Kebeish, R.M. 2008. Metabolic engineering towards the enhancement of photosynthesis. Photochemistry and Photobiology 84: 1317-1323.

Rasineni, G.K., Loh, P.C. \& Lim, B.H. 2017. Characterization of Chlamydomonas ribulose-1,5-bisphosphate carboxylase/ oxygenase variants mutated at residues that are posttranslationally modified. Biochimica et Biophysica Acta 1861(2): 79-85

Saschenbrecker, S., Bracher, A., Rao, K.V., Rao, B.V., Hartl, F.U . \& Hayer-Hartl, M. 2007. Structure and function of RbcX, an assembly chaperone for hexadecameric Rubisco. Cell 129: 1189-1200.

Smith, S.A. \& Tabita, F.R. 2003. Positive and negative selection of mutant forms of prokaryotic (cyanobacterial) ribulose-1,5bisphosphate carboxylase/oxygenase. Journal of Molecular Biology 331: 557-569.

Spreitzer, R.J., Thow, G. \& Zhu, G. 1995. Pseudoreversion substitution at large-subunit residue 54 influences the $\mathrm{CO}_{2} / \mathrm{O}_{2}$ specificity of chloroplast ribulose bisphosphate carboxylase/ oxygenase. Plant Physiology 109: 681-685.

Stan, G., Brooks, B.R., Lorimer, G.H. \& Thirumalai, D. 2006. Residues in substrate proteins that interact with GroEL in the capture process are buried in the native state. Proceedings of the National Academy of Science of the United States of America 103: 4433-4438.

Stan, G., Brooks, B.R., Lorimer, G.H. \& Thirumalai, D. 2004. Identifying natural substrates for chaperonins using a sequence-based approach. Protein Science 14: 193-201.

Tabita, F.R., Hanson, T.E., Satagopan, S., Witte, B.H. \& Kreel, N.E. 2008. Phylogenetic and evolutionary relationships of RubisCO and the RubisCO-like proteins and the functional lessons provided by diverse molecular forms. Philosophical Transactions of the Royal Society B 363: 2629-2640.

Tabita, F.R., Hanson, T.E., Li, H., Satagopan, S., Singh, J. \& Chan, S. 2007a. Function, structure, and evolution of the RubisCOlike proteins and their RubisCO homologs. Microbiology and Molecular Biology Reviews 71(4): 576-599.

Tabita, F.R., Satagopan, S., Hanson, T.E., Kreel, N.E. \& Scott, S.S. 2007b. Distinct form I, II, III, and IV Rubisco proteins from the three kingdoms of life provide clues about Rubisco evolution and structure/function relationships. Journal of Experimental Botany 59: 1515-1524.

Takano, K., Yamagata, Y. \& Yutani, K. 2001. Contribution of polar groups in the interior of a protein to the conformational stability. Biochemistry 40: 4853-4858.

Taylor, T.C., Backlund, A., Bjorhall, K., Spreitzer, R.J. \& Andersson, I. 2001. First crystal structure of Rubisco from a green alga, Chlamydomonas reinhardtii. Journal of Biological Chemistry 276: 48159-48164.

Tcherkez, G.G.B.,Farquhar, G.D. \& Andrews, T.J. 2006. Despite slow catalysis and confused substrate specificity, all ribulose bisphosphate carboxylases may be nearly perfectly optimized. Proceedings of the National Academy of Science of the United States of America 103: 7246-7251. 
Whitney, S.M., Baldet, P., Hudson, G.S. \& Andrews, T.J. 2001. Form I Rubiscos from non-green algae are expressed abundantly but not assembled in tobacco chloroplasts. Plant Journal 26: 535-547.

Whitney, S.M., Houtz, R.L. \& Alonso, H. 2011. Advancing our understanding and capacity to engineer nature's $\mathrm{CO}_{2}-$ sequestering enzyme, Rubisco. Plant Physiology 155: 27-35.

Wilson, R.H., Martin-Avila, E., Conlan, C. \& Whitney, S.M. 2017. An improved Escherichia coli screen for Rubisco identifies a protein-protein interface that can enhance $\mathrm{CO}_{2}$ fixation kinetics. Journal of Biological Chemistry 293: 18-27.

Wostrikoff, K. \& Stern, D. 2007. Rubisco large-subunit translation is autoregulated in response to its assembly state in tobacco chloroplasts. Proceedings of the National Academy of Science of the United States of America 104: 6466-6471.

Zhu, X.G., Portis, A.R. \& Long, S.P. 2004. Would transformation of $\mathrm{C} 3$ crop plants with foreign Rubisco increase productivity? A computational analysis extrapolating from kinetic properties to canopy photosynthesis. Plant, Cell and Environment 27: 155-165.
Yee Hung Yeap, Teng Wei Koay \& Boon Hoe Lim* Department of Chemical Science

Universiti Tunku Abdul Rahman 31900 Kampar, Perak Darul Ridzuan Malaysia

\section{Hann Ling Wong}

Department of Biological Science

Universiti Tunku Abdul Rahman

31900 Kampar, Perak Darul Ridzuan

Malaysia

*Corresponding author; email: bhlim@utar.edu.my

Received: 14 Mac 2018

Accepted: 4 June 2018 


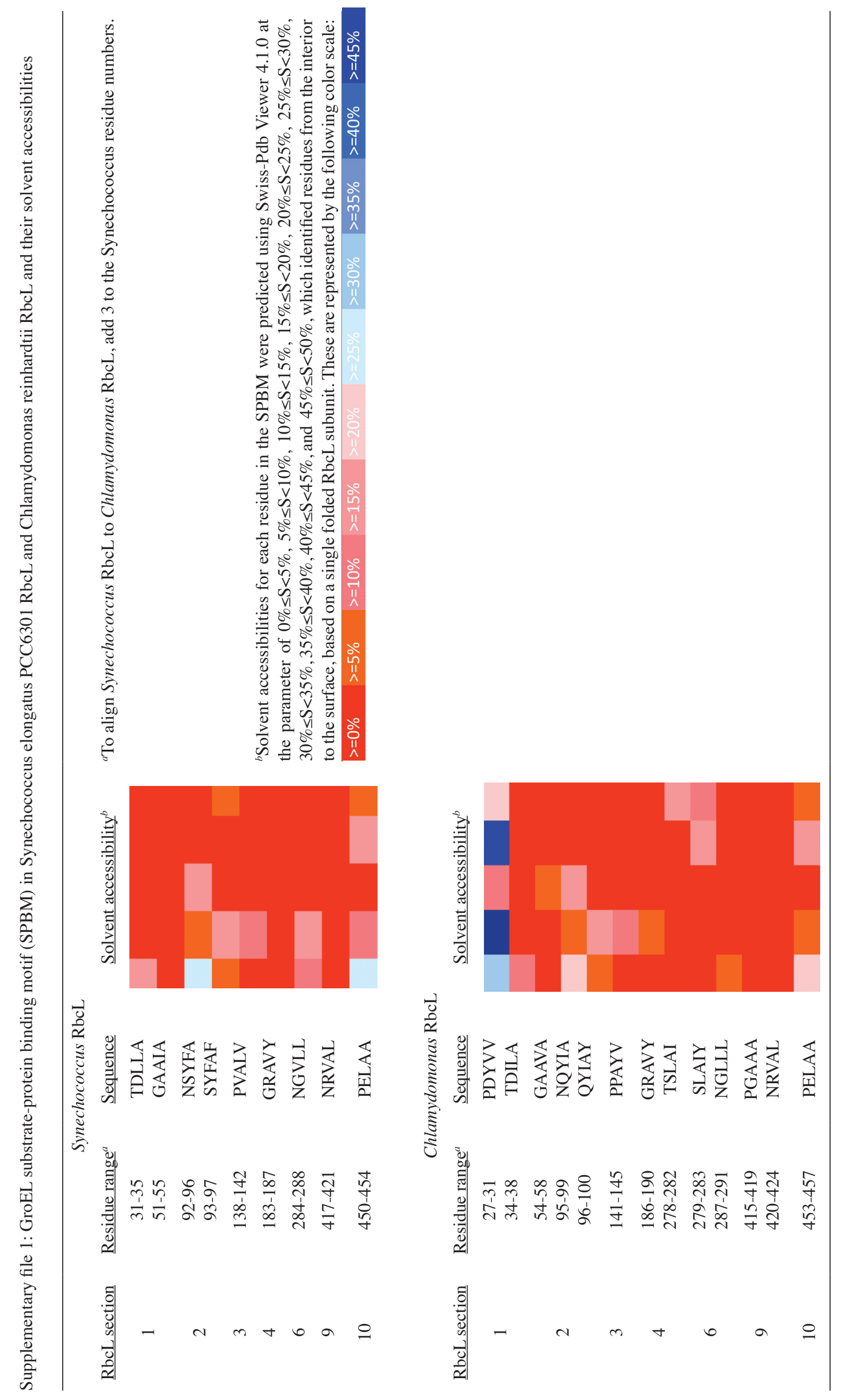


SUPPLEMENTARY FILE 2: Average hydropathy index of seven-residue segments on Chlamydomonas and Synechococcus RbcL

\begin{tabular}{|c|c|c|c|c|}
\hline \multirow[b]{2}{*}{${ }^{a}$ Residue range } & \multicolumn{2}{|c|}{ Chlamydomonas RbcL } & \multicolumn{2}{|c|}{ Synechococcus RbcL } \\
\hline & Sequence & $\begin{array}{c}\text { Hydropathy } \\
\text { index }\end{array}$ & Sequence & $\begin{array}{l}\text { Hydropathy } \\
\text { index }\end{array}$ \\
\hline $1-7$ & MVPQTET & -0.5571 & MPKTQSA & -0.9714 \\
\hline $2-8$ & VPQTETK & -1.3857 & $b^{\prime}$ & $b^{-}$ \\
\hline $3-9$ & PQTETKA & -1.7286 & PKTQSAA & -0.9857 \\
\hline $4-10$ & QTETKAG & -1.5571 & KTQSAAG & -0.8143 \\
\hline $5-11$ & TETKAGA & -0.8000 & $b_{-}$ & $b_{-}$ \\
\hline $6-12$ & ETKAGAG & -0.7571 & $b^{b}$ & ${ }^{b}$ \\
\hline $7-13$ & TKAGAGF & 0.1429 & TQSAAGY & -0.4429 \\
\hline $8-14$ & KAGAGFK & -0.3143 & QSAAGYK & -0.9000 \\
\hline $9-15$ & AGAGFKA & 0.5000 & SAAGYKA & -0.1429 \\
\hline $10-16$ & GAGFKAG & 0.1857 & AAGYKAG & -0.0857 \\
\hline $11-17$ & AGFKAGV & 0.8429 & AGYKAGV & 0.2571 \\
\hline $12-18$ & GFKAGVK & 0.0286 & GYKAGVK & -0.5571 \\
\hline $13-19$ & FKAGVKD & -0.4143 & YKAGVKD & -1.0000 \\
\hline $14-20$ & KAGVKDY & -1.0000 & KAGVKDY & -1.0000 \\
\hline $15-21$ & AGVKDYR & -1.0857 & AGVKDYK & -1.0000 \\
\hline $16-22$ & GVKDYRL & -0.8000 & GVKDYKL & -0.7143 \\
\hline $17-23$ & VKDYRLT & -0.8429 & VKDYKLT & -0.7571 \\
\hline $18-24$ & KDYRLTY & -1.6286 & KDYKLTY & -1.5429 \\
\hline $19-25$ & DYRLTYY & -1.2571 & DYKLTYY & -1.1714 \\
\hline $20-26$ & YRLTYYT & -0.8571 & YKLTYYT & -0.7714 \\
\hline $21-27$ & RLTYYTP & -0.9000 & KLTYYTP & -0.8143 \\
\hline $22-28$ & LTYYTPD & -0.7571 & LTYYTPD & -0.7571 \\
\hline $23-29$ & TYYTPDY & -1.4857 & TYYTPDY & -1.4857 \\
\hline $24-30$ & YYTPDYV & -0.7857 & YYTPDYT & -1.4857 \\
\hline $25-31$ & YTPDYVV & 0.0000 & YTPDYTP & -1.5286 \\
\hline $26-32$ & TPDYVVR & -0.4571 & TPDYTPK & -1.9000 \\
\hline $27-33$ & PDYVVRD & -0.8571 & PDYTPKD & -2.3000 \\
\hline $28-34$ & DYVVRDT & -0.7286 & DYTPKDT & -2.1714 \\
\hline $29-35$ & YVVRDTD & -0.7286 & YTPKDTD & -2.1714 \\
\hline $30-36$ & VVRDTDI & 0.1000 & TPKDTDL & -1.4429 \\
\hline $31-37$ & VRDTDIL & 0.0429 & PKDTDLL & -0.8000 \\
\hline $32-38$ & RDTDILA & -0.3000 & KDTDLLA & -0.3143 \\
\hline $33-39$ & DTDILAA & 0.6000 & DTDLLAA & 0.5000 \\
\hline $34-40$ & TDILAAF & 1.5000 & TDLLAAF & 1.4000 \\
\hline $35-41$ & DILAAFR & 0.9571 & DLLAAFR & 0.8571 \\
\hline $36-42$ & ILAAFRM & 1.7286 & LLAAFRF & 1.7571 \\
\hline $37-43$ & LAAFRMT & 0.9857 & LAAFRFS & 1.1000 \\
\hline $38-44$ & AAFRMTP & 0.2143 & AAFRFSP & 0.3286 \\
\hline $39-45$ & AFRMTPQ & -0.5429 & AFRFSPQ & -0.4286 \\
\hline $40-46$ & FRMTPQP & -1.0286 & FRFSPQP & -0.9143 \\
\hline $41-47$ & RMTPQPG & -1.4857 & RFSPQPG & -1.3714 \\
\hline $42-48$ & MTPQPGV & -0.2429 & FSPQPGV & -0.1286 \\
\hline $43-49$ & TPQPGVP & -0.7429 & SPQPGVP & -0.7571 \\
\hline $44-50$ & PQPGVPP & -0.8714 & PQPGVPA & -0.3857 \\
\hline $45-51$ & QPGVPPE & -1.1429 & QPGVPAD & -0.6571 \\
\hline $46-52$ & PGVPPEE & -1.1429 & PGVPADE & -0.6571 \\
\hline $47-53$ & GVPPEEC & -0.5571 & GVPADEA & -0.1714 \\
\hline $48-54$ & VPPEECG & -0.5571 & VPADEAG & -0.1714 \\
\hline $49-55$ & PPEECGA & -0.9000 & PADEAGA & -0.5143 \\
\hline
\end{tabular}


Continued SUPPLEMENTARY FILE 2

\begin{tabular}{|c|c|c|c|c|}
\hline $50-56$ & PEECGAA & -0.4143 & ADEAGAA & -0.0286 \\
\hline $51-57$ & EECGAAV & 0.4143 & DEAGAAI & 0.3571 \\
\hline $52-58$ & ECGAAVA & 1.1714 & EAGAAIA & 1.1143 \\
\hline $53-59$ & CGAAVAA & 1.9286 & AGAAIAA & 1.8714 \\
\hline $54-60$ & GAAVAAE & 1.0714 & GAAIAAE & 1.1143 \\
\hline $55-61$ & AAVAAES & 1.0143 & AAIAAES & 1.0571 \\
\hline $56-62$ & AVAAESS & 0.6429 & AIAAESS & 0.6857 \\
\hline $57-63$ & VAAESST & 0.2857 & IAAESST & 0.3286 \\
\hline $58-64$ & AAESSTG & -0.3714 & AAESSTG & -0.3714 \\
\hline $59-65$ & AESSTGT & -0.7286 & AESSTGT & -0.7286 \\
\hline $60-66$ & ESSTGTW & -1.1143 & ESSTGTW & -1.1143 \\
\hline $61-67$ & SSTGTWT & -0.7143 & SSTGTWT & -0.7143 \\
\hline $62-68$ & STGTWTT & -0.7000 & STGTWTT & -0.7000 \\
\hline $63-69$ & TGTWTTV & 0.0143 & TGTWTTV & 0.0143 \\
\hline $64-70$ & GTWTTVW & -0.0143 & GTWTTVW & -0.0143 \\
\hline $65-71$ & TWTTVWT & -0.0571 & TWTTVWT & -0.0571 \\
\hline $66-72$ & WTTVWTD & -0.4571 & WTTVWTD & -0.4571 \\
\hline $67-73$ & TTVWTDG & -0.3857 & TTVWTDL & 0.2143 \\
\hline $68-74$ & TVWTDGL & 0.2571 & TVWTDLL & 0.8571 \\
\hline $69-75$ & VWTDGLT & 0.2571 & VWTDLLT & 0.8571 \\
\hline $70-76$ & WTDGLTS & -0.4571 & WTDLLTD & -0.2429 \\
\hline $71-77$ & TDGLTSL & 0.2143 & TDLLTDM & 0.1571 \\
\hline $72-78$ & DGLTSLD & -0.1857 & DLLTDMD & -0.2429 \\
\hline $73-79$ & GLTSLDR & -0.3286 & LLTDMDR & -0.3857 \\
\hline $74-80$ & LTSLDRY & -0.4571 & LTDMDRY & -1.1143 \\
\hline $75-81$ & TSLDRYK & -1.5571 & TDMDRYK & -2.2143 \\
\hline $76-82$ & SLDRYKG & -1.5143 & DMDRYKG & -2.1714 \\
\hline $77-83$ & LDRYKGR & -2.0429 & MDRYKGK & -2.2286 \\
\hline $78-84$ & DRYKGRC & -2.2286 & DRYKGKC & -2.1429 \\
\hline $79-85$ & RYKGRCY & -1.9143 & RYKGKCY & -1.8286 \\
\hline $80-86$ & YKGRCYD & -1.7714 & YKGKCYH & -1.6429 \\
\hline $81-87$ & KGRCYDI & -0.9429 & KGKCYHI & -0.8143 \\
\hline $82-88$ & GRCYDIE & -0.8857 & GKCYHIE & -0.7571 \\
\hline 83-89 & RCYDIEP & -1.0571 & KCYHIEP & -0.9286 \\
\hline $84-90$ & CYDIEPV & 0.1857 & CYHIEPV & 0.2286 \\
\hline $85-91$ & YDIEPVP & -0.4000 & YHIEPVQ & -0.6286 \\
\hline $86-92$ & DIEPVPG & -0.2714 & HIEPVQG & -0.5000 \\
\hline $87-93$ & IEPVPGE & -0.2714 & IEPVQGE & -0.5429 \\
\hline $88-94$ & EPVPGED & -1.4143 & EPVQGEE & -1.6857 \\
\hline $89-95$ & PVPGEDN & -1.4143 & PVQGEEN & -1.6857 \\
\hline $90-96$ & VPGEDNQ & -1.6857 & VQGEENS & -1.5714 \\
\hline $91-97$ & PGEDNQY & -2.4714 & QGEENSY & -2.3571 \\
\hline $92-98$ & GEDNQYI & -1.6000 & GEENSYF & -1.4571 \\
\hline $93-99$ & EDNQYIA & -1.2857 & EENSYFA & -1.1429 \\
\hline $94-100$ & DNQYIAY & -0.9714 & ENSYFAF & -0.2429 \\
\hline 95-101 & NQYIAYV & 0.1286 & NSYFAFI & 0.9000 \\
\hline $96-102$ & QYIAYVA & 0.8857 & SYFAFIA & 1.6571 \\
\hline $97-103$ & YIAYVAY & 1.2000 & YFAFIAY & 1.5857 \\
\hline 98-104 & IAYVAYP & 1.1571 & FAFIAYP & 1.5429 \\
\hline 99-105 & AYVAYPI & 1.1571 & AFIAYPL & 1.6857 \\
\hline 100-106 & YVAYPID & 0.4000 & FIAYPLD & 0.9286 \\
\hline 101-107 & VAYPIDL & 1.1286 & IAYPLDL & 1.0714 \\
\hline $102-108$ & AYPIDLF & 0.9286 & AYPLDLF & 0.8286 \\
\hline
\end{tabular}


Continued SUPPLEMENTARY FILE 2

\begin{tabular}{|c|c|c|c|c|}
\hline 103-109 & YPIDLFE & 0.1714 & YPLDLFE & 0.0714 \\
\hline $104-110$ & PIDLFEE & -0.1429 & PLDLFEE & -0.2429 \\
\hline $105-111$ & IDLFEEG & 0.0286 & LDLFEEG & -0.0714 \\
\hline $106-112$ & DLFEEGS & -0.7286 & DLFEEGS & -0.7286 \\
\hline $107-113$ & LFEEGSV & 0.3714 & LFEEGSV & 0.3714 \\
\hline $108-114$ & FEEGSVT & -0.2714 & FEEGSVT & -0.2714 \\
\hline $109-115$ & EEGSVTN & -1.1714 & EEGSVTN & -1.1714 \\
\hline $110-116$ & EGSVTNM & -0.4000 & EGSVTNI & -0.0286 \\
\hline $111-117$ & GSVTNMF & 0.5000 & GSVTNIL & 1.0143 \\
\hline $112-118$ & SVTNMFT & 0.4571 & SVTNILT & 0.9714 \\
\hline 113-119 & VTNMFTS & 0.4571 & VTNILTS & 0.9714 \\
\hline $114-120$ & TNMFTSI & 0.5000 & TNILTSI & 1.0143 \\
\hline $115-121$ & NMFTSIV & 1.2000 & NILTSIV & 1.7143 \\
\hline $116-122$ & MFTSIVG & 1.6429 & ILTSIVG & 2.1571 \\
\hline $117-123$ & FTSIVGN & 0.8714 & LTSIVGN & 1.0143 \\
\hline $118-124$ & TSIVGNV & 1.0714 & TSIVGNV & 1.0714 \\
\hline $119-125$ & SIVGNVF & 1.5714 & SIVGNVF & 1.5714 \\
\hline $120-126$ & IVGNVFG & 1.6286 & IVGNVFG & 1.6286 \\
\hline $121-127$ & VGNVFGF & 1.3857 & VGNVFGF & 1.3857 \\
\hline $122-128$ & GNVFGFK & 0.2286 & GNVFGFK & 0.2286 \\
\hline $123-129$ & NVFGFKA & 0.5429 & NVFGFKA & 0.5429 \\
\hline $124-130$ & VFGFKAL & 1.5857 & VFGFKAI & 1.6857 \\
\hline $125-131$ & FGFKALR & 0.3429 & FGFKAIR & 0.4429 \\
\hline $126-132$ & GFKALRA & 0.2000 & GFKAIRS & -0.0714 \\
\hline $127-133$ & FKALRAL & 0.8000 & FKAIRSL & 0.5286 \\
\hline $128-134$ & KALRALR & -0.2429 & KAIRSLR & -0.5143 \\
\hline $129-135$ & ALRALRL & 0.8571 & AIRSLRL & 0.5857 \\
\hline $130-136$ & LRALRLE & 0.1000 & IRSLRLE & -0.1714 \\
\hline $131-137$ & RALRLED & -0.9429 & RSLRLED & -1.3143 \\
\hline $132-138$ & ALRLEDL & 0.2429 & SLRLEDI & -0.0286 \\
\hline 133-139 & LRLEDLR & -0.6571 & LRLEDIR & -0.5571 \\
\hline $134-140$ & RLEDLRI & -0.5571 & RLEDIRF & -0.7000 \\
\hline $135-141$ & LEDLRIP & -0.1429 & LEDIRFP & -0.2857 \\
\hline $136-142$ & EDLRIPP & -0.9143 & EDIRFPV & -0.2286 \\
\hline $137-143$ & DLRIPPA & -0.1571 & DIRFPVA & 0.5286 \\
\hline $138-144$ & LRIPPAY & 0.1571 & IRFPVAL & 1.5714 \\
\hline $139-145$ & RIPPAYV & 0.2143 & RFPVALV & 1.5286 \\
\hline $140-146$ & IPPAYVK & 0.3000 & FPVALVK & 1.6143 \\
\hline $141-147$ & PPAYVKT & -0.4429 & PVALVKT & 1.1143 \\
\hline $142-148$ & PAYVKTF & 0.1857 & VALVKTF & 1.7429 \\
\hline $143-149$ & AYVKTFV & 1.0143 & ALVKTFQ & 0.6429 \\
\hline $144-150$ & YVKTFVG & 0.7000 & LVKTFQG & 0.3286 \\
\hline $145-151$ & VKTFVGP & 0.6571 & VKTFQGP & -0.4429 \\
\hline $146-152$ & KTFVGPP & -0.1714 & KTFQGPP & -1.2714 \\
\hline $147-153$ & TFVGPPH & -0.0714 & TFQGPPH & -1.1714 \\
\hline $148-154$ & FVGPPHG & -0.0286 & FQGPPHG & -1.1286 \\
\hline $149-155$ & VGPPHGI & 0.2143 & QGPPHGI & -0.8857 \\
\hline $150-156$ & GPPHGIQ & -0.8857 & GPPHGIQ & -0.8857 \\
\hline $151-157$ & PPHGIQV & -0.2286 & PPHGIQV & -0.2286 \\
\hline $152-158$ & PHGIQVE & -0.5000 & PHGIQVE & -0.5000 \\
\hline $153-159$ & HGIQVER & -0.9143 & HGIQVER & -0.9143 \\
\hline $154-160$ & GIQVERD & -0.9571 & GIQVERD & -0.9571 \\
\hline $155-161$ & IQVERDK & -1.4571 & IQVERDL & -0.3571 \\
\hline
\end{tabular}


Continued SUPPLEMENTARY FILE 2

\begin{tabular}{|c|c|c|c|c|}
\hline $156-162$ & QVERDKL & -1.5571 & QVERDLL & -0.4571 \\
\hline $157-163$ & VERDKLN & -1.5571 & VERDLLN & -0.4571 \\
\hline $158-164$ & ERDKLNK & -2.7143 & ERDLLNK & -1.6143 \\
\hline $159-165$ & RDKLNKY & -2.4000 & RDLLNKY & -1.3000 \\
\hline $160-166$ & DKLNKYG & -1.8143 & DLLNKYG & -0.7143 \\
\hline $161-167$ & KLNKYGR & -1.9571 & LLNKYGR & -0.8571 \\
\hline $162-168$ & LNKYGRG & -1.4571 & LNKYGRP & -1.6286 \\
\hline $163-169$ & NKYGRGL & -1.4571 & NKYGRPM & -1.9000 \\
\hline $164-170$ & KYGRGLL & -0.4143 & KYGRPML & -0.8571 \\
\hline $165-171$ & YGRGLLG & 0.0857 & YGRPMLG & -0.3571 \\
\hline $166-172$ & GRGLLGC & 0.6286 & GRPMLGC & 0.1857 \\
\hline $167-173$ & RGLLGCT & 0.5857 & RPMLGCT & 0.1429 \\
\hline $168-174$ & GLLGCTI & 1.8714 & PMLGCTI & 1.4286 \\
\hline $169-175$ & LLGCTIK & 1.3714 & MLGCTIK & 1.1000 \\
\hline $170-176$ & LGCTIKP & 0.6000 & LGCTIKP & 0.6000 \\
\hline $171-177$ & GCTIKPK & -0.5000 & GCTIKPK & -0.5000 \\
\hline $172-178$ & CTIKPKL & 0.1000 & CTIKPKL & 0.1000 \\
\hline $173-179$ & TIKPKLG & -0.3143 & TIKPKLG & -0.3143 \\
\hline $174-180$ & IKPKLGL & 0.3286 & IKPKLGL & 0.3286 \\
\hline $175-181$ & KPKLGLS & -0.4286 & KPKLGLS & -0.4286 \\
\hline 176-182 & PKLGLSA & 0.3857 & PKLGLSA & 0.3857 \\
\hline $177-183$ & KLGLSAK & 0.0571 & KLGLSAK & 0.0571 \\
\hline $178-184$ & LGLSAKN & 0.1143 & LGLSAKN & 0.1143 \\
\hline $179-185$ & GLSAKNY & -0.6143 & GLSAKNY & -0.6143 \\
\hline 180-186 & LSAKNYG & -0.6143 & LSAKNYG & -0.6143 \\
\hline $181-187$ & SAKNYGR & -1.8000 & SAKNYGR & -1.8000 \\
\hline $182-188$ & AKNYGRA & -1.4286 & AKNYGRA & -1.4286 \\
\hline $183-189$ & KNYGRAV & -1.0857 & KNYGRAV & -1.0857 \\
\hline $184-190$ & NYGRAVY & -0.7143 & NYGRAVY & -0.7143 \\
\hline $185-191$ & YGRAVYE & -0.7143 & YGRAVYE & -0.7143 \\
\hline 186-192 & GRAVYEC & -0.1714 & GRAVYEC & -0.1714 \\
\hline 187-193 & RAVYECL & 0.4286 & RAVYECL & 0.4286 \\
\hline 188-194 & AVYECLR & 0.4286 & AVYECLR & 0.4286 \\
\hline $189-195$ & VYECLRG & 0.1143 & VYECLRG & 0.1143 \\
\hline 190-196 & YECLRGG & -0.5429 & YECLRGG & -0.5429 \\
\hline 191-197 & ECLRGGL & 0.1857 & ECLRGGL & 0.1857 \\
\hline $192-198$ & CLRGGLD & 0.1857 & CLRGGLD & 0.1857 \\
\hline 193-199 & LRGGLDF & 0.2286 & LRGGLDF & 0.2286 \\
\hline $194-200$ & RGGLDFT & -0.4143 & RGGLDFT & -0.4143 \\
\hline $195-201$ & GGLDFTK & -0.3286 & GGLDFTK & -0.3286 \\
\hline 196-202 & GLDFTKD & -0.7714 & GLDFTKD & -0.7714 \\
\hline $197-203$ & LDFTKDD & -1.2143 & LDFTKDD & -1.2143 \\
\hline 198-204 & DFTKDDE & -2.2571 & DFTKDDE & -2.2571 \\
\hline 199-205 & FTKDDEN & -2.2571 & FTKDDEN & -2.2571 \\
\hline 200-206 & TKDDENV & -2.0571 & TKDDENI & -2.0143 \\
\hline 201-207 & KDDENVN & -2.4571 & KDDENIN & -2.4143 \\
\hline 202-208 & DDENVNS & -2.0143 & DDENINS & -1.9714 \\
\hline 203-209 & DENVNSQ & -2.0143 & DENINSQ & -1.9714 \\
\hline 204-210 & ENVNSQP & -1.7429 & ENINSQP & -1.7000 \\
\hline $205-211$ & NVNSQPF & -0.8429 & NINSQPF & -0.8000 \\
\hline 206-212 & VNSQPFM & -0.0714 & INSQPFQ & -0.8000 \\
\hline $207-213$ & NSQPFMR & -1.3143 & NSQPFQR & -2.0857 \\
\hline $208-214$ & SQPFMRW & -0.9429 & SQPFQRW & -1.7143 \\
\hline
\end{tabular}


Continued SUPPLEMENTARY FILE 2

\begin{tabular}{|c|c|c|c|c|}
\hline $209-215$ & QPFMRWR & -1.4714 & QPFQRWR & -2.2429 \\
\hline $210-216$ & PFMRWRD & -1.4714 & PFQRWRD & -2.2429 \\
\hline $211-217$ & FMRWRDR & -1.8857 & FQRWRDR & -2.6571 \\
\hline $212-218$ & MRWRDRF & -1.8857 & QRWRDRF & -2.6571 \\
\hline $213-219$ & RWRDRFL & -1.6143 & RWRDRFL & -1.6143 \\
\hline $214-220$ & WRDRFLF & -0.5714 & WRDRFLF & -0.5714 \\
\hline $215-221$ & RDRFLFV & 0.1571 & RDRFLFV & 0.1571 \\
\hline $216-222$ & DRFLFVA & 1.0571 & DRFLFVA & 1.0571 \\
\hline $217-223$ & RFLFVAE & 1.0571 & RFLFVAD & 1.0571 \\
\hline $218-224$ & FLFVAEA & 1.9571 & FLFVADA & 1.9571 \\
\hline $219-225$ & LFVAEAI & 2.2000 & LFVADAI & 2.2000 \\
\hline $220-226$ & FVAEAIY & 1.4714 & FVADAIH & 1.2000 \\
\hline $221-227$ & VAEAIYK & 0.5143 & VADAIHK & 0.2429 \\
\hline $222-228$ & AEAIYKA & 0.1714 & ADAIHKS & -0.4714 \\
\hline $223-229$ & EAIYKAQ & -0.5857 & DAIHKSQ & -1.2286 \\
\hline $224-230$ & AIYKAQA & 0.1714 & AIHKSQA & -0.4714 \\
\hline $225-231$ & IYKAQAE & -0.5857 & IHKSQAE & -1.2286 \\
\hline $226-232$ & YKAQAET & -1.3286 & HKSQAET & -1.9714 \\
\hline $227-233$ & KAQAETG & -1.2000 & KSQAETG & -1.5714 \\
\hline $228-234$ & AQAETGE & -1.1429 & SQAETGE & -1.5143 \\
\hline $229-235$ & QAETGEV & -0.8000 & QAETGEI & -0.7571 \\
\hline $230-236$ & AETGEVK & -0.8571 & AETGEIK & -0.8143 \\
\hline $231-237$ & ETGEVKG & -1.1714 & ETGEIKG & -1.1286 \\
\hline $232-238$ & TGEVKGH & -1.1286 & TGEIKGH & -1.0857 \\
\hline $233-239$ & GEVKGHY & -1.2143 & GEIKGHY & -1.1714 \\
\hline $234-240$ & EVKGHYL & -0.6143 & EIKGHYL & -0.5714 \\
\hline $235-241$ & VKGHYLN & -0.6143 & IKGHYLN & -0.5714 \\
\hline $236-242$ & KGHYLNA & -0.9571 & KGHYLNV & -0.6143 \\
\hline $237-243$ & GHYLNAT & -0.5000 & GHYLNVT & -0.1571 \\
\hline $238-244$ & HYLNATA & -0.1857 & HYLNVTA & 0.1571 \\
\hline $239-245$ & YLNATAG & 0.2143 & YLNVTAP & 0.3857 \\
\hline $240-246$ & LNATAGT & 0.3000 & LNVTAPT & 0.4714 \\
\hline $241-247$ & NATAGTC & 0.1143 & NVTAPTC & 0.2857 \\
\hline $242-248$ & ATAGTCE & 0.1143 & VTAPTCE & 0.2857 \\
\hline $243-249$ & TAGTCEE & -0.6429 & TAPTCEE & -0.8143 \\
\hline $244-250$ & AGTCEEM & -0.2714 & APTCEEM & -0.4429 \\
\hline $245-251$ & GTCEEMM & -0.2571 & PTCEEMM & -0.4286 \\
\hline $246-252$ & TCEEMMK & -0.7571 & TCEEMMK & -0.7571 \\
\hline $247-253$ & CEEMMKR & -1.3000 & CEEMMKR & -1.3000 \\
\hline $248-254$ & EEMMKRA & -1.4000 & EEMMKRA & -1.4000 \\
\hline $249-255$ & EMMKRAV & -0.3000 & EMMKRAE & -1.4000 \\
\hline $250-256$ & MMKRAVC & 0.5571 & MMKRAEF & -0.5000 \\
\hline $251-257$ & MKRAVCA & 0.5429 & MKRAEFA & -0.5143 \\
\hline $252-258$ & KRAVCAK & -0.2857 & KRAEFAK & -1.3429 \\
\hline $253-259$ & RAVCAKE & -0.2286 & RAEFAKE & -1.2857 \\
\hline $254-260$ & AVCAKEL & 0.9571 & AEFAKEL & -0.1000 \\
\hline $255-261$ & VCAKELG & 0.6429 & EFAKELG & -0.4143 \\
\hline $256-262$ & CAKELGV & 0.6429 & FAKELGM & 0.3571 \\
\hline $257-263$ & AKELGVP & 0.0571 & AKELGMP & -0.2714 \\
\hline $258-264$ & KELGVPI & 0.4429 & KELGMPI & 0.1143 \\
\hline $259-265$ & ELGVPII & 1.6429 & ELGMPII & 1.3143 \\
\hline $260-266$ & LGVPIIM & 2.4143 & LGMPIIM & 2.0857 \\
\hline $261-267$ & GVPIIMH & 1.4143 & GMPIIMH & 1.0857 \\
\hline
\end{tabular}


Continued SUPPLEMENTARY FILE 2

\begin{tabular}{|c|c|c|c|c|}
\hline $262-268$ & VPIIMHD & 0.9714 & MPIIMHD & 0.6429 \\
\hline 263-269 & PIIMHDY & 0.1857 & PIIMHDF & 0.7714 \\
\hline $264-270$ & IIMHDYL & 0.9571 & IIMHDFL & 1.5429 \\
\hline $265-271$ & IMHDYLT & 0.2143 & IMHDFLT & 0.8000 \\
\hline $266-272$ & MHDYLTG & -0.4857 & MHDFLTA & 0.4143 \\
\hline $267-273$ & HDYLTGG & -0.8143 & HDFLTAG & 0.0857 \\
\hline $268-274$ & DYLTGGF & 0.0429 & DFLTAGF & 0.9429 \\
\hline $269-275$ & YLTGGFT & 0.4429 & FLTAGFT & 1.3429 \\
\hline $270-276$ & LTGGFTA & 0.8857 & LTAGFTA & 1.2000 \\
\hline $271-277$ & TGGFTAN & -0.1571 & TAGFTAN & 0.1571 \\
\hline $272-278$ & GGFTANT & -0.1571 & AGFTANT & 0.1571 \\
\hline $273-279$ & GFTANTS & -0.2143 & GFTANTT & -0.2000 \\
\hline $274-280$ & FTANTSL & 0.3857 & FTANTTL & 0.4000 \\
\hline $275-281$ & TANTSLA & 0.2429 & TANTTLA & 0.2571 \\
\hline $276-282$ & ANTSLAI & 0.9857 & ANTTLAK & -0.2000 \\
\hline $277-283$ & NTSLAIY & 0.5429 & NTTLAKW & -0.5857 \\
\hline $278-284$ & TSLAIYC & 1.4000 & TTLAKWC & 0.2714 \\
\hline $279-285$ & SLAIYCR & 0.8571 & TLAKWCR & -0.2714 \\
\hline $280-286$ & LAIYCRD & 0.4714 & LAKWCRD & -0.6714 \\
\hline $281-287$ & AIYCRDN & -0.5714 & AKWCRDN & -1.7143 \\
\hline $282-288$ & IYCRDNG & -0.8857 & KWCRDNG & -2.0286 \\
\hline 283-289 & YCRDNGL & -0.9857 & WCRDNGV & -0.8714 \\
\hline $284-290$ & CRDNGLL & -0.2571 & CRDNGVL & -0.2000 \\
\hline $285-291$ & RDNGLLL & -0.0714 & RDNGVLL & -0.0143 \\
\hline $286-292$ & DNGLLLH & 0.1143 & DNGVLLH & 0.1714 \\
\hline $287-293$ & NGLLLHI & 1.2571 & NGVLLHI & 1.3143 \\
\hline $288-294$ & GLLLHIH & 1.3000 & GVLLHIH & 1.3571 \\
\hline $289-295$ & LLLHIHR & 0.7143 & VLLHIHR & 0.7714 \\
\hline $290-296$ & LLHIHRA & 0.4286 & LLHIHRA & 0.4286 \\
\hline $291-297$ & LHIHRAM & 0.1571 & LHIHRAM & 0.1571 \\
\hline $292-298$ & HIHRAMH & -0.8429 & HIHRAMH & -0.8429 \\
\hline 293-299 & IHRAMHA & -0.1286 & IHRAMHA & -0.1286 \\
\hline 294-300 & HRAMHAV & -0.1714 & HRAMHAV & -0.1714 \\
\hline 295-301 & RAMHAVI & 0.9286 & RAMHAVI & 0.9286 \\
\hline 296-302 & AMHAVID & 1.0714 & AMHAVID & 1.0714 \\
\hline $297-303$ & MHAVIDR & 0.1714 & MHAVIDR & 0.1714 \\
\hline $298-304$ & HAVIDRQ & -0.6000 & HAVIDRQ & -0.6000 \\
\hline 299-305 & AVIDRQR & -0.7857 & AVIDRQR & -0.7857 \\
\hline $300-306$ & VIDRQRN & -1.5429 & VIDRQRN & -1.5429 \\
\hline $301-307$ & IDRQRNH & -2.6000 & IDRQRNH & -2.6000 \\
\hline $302-308$ & DRQRNHG & -3.3000 & DRQRNHG & -3.3000 \\
\hline 303-309 & RQRNHGI & -2.1571 & RQRNHGI & -2.1571 \\
\hline $304-310$ & QRNHGIH & -1.9714 & QRNHGIH & -1.9714 \\
\hline $305-311$ & RNHGIHF & -1.0714 & RNHGIHF & -1.0714 \\
\hline $306-312$ & NHGIHFR & -1.0714 & NHGIHFR & -1.0714 \\
\hline $307-313$ & HGIHFRV & 0.0286 & HGIHFRV & 0.0286 \\
\hline $308-314$ & GIHFRVL & 1.0286 & GIHFRVL & 1.0286 \\
\hline $309-315$ & IHFRVLA & 1.3429 & IHFRVLA & 1.3429 \\
\hline $310-316$ & HFRVLAK & 0.1429 & HFRVLAK & 0.1429 \\
\hline $311-317$ & FRVLAKA & 0.8571 & FRVLAKC & 0.9571 \\
\hline $312-318$ & RVLAKAL & 1.0000 & RVLAKCL & 1.1000 \\
\hline 313-319 & VLAKALR & 1.0000 & VLAKCLR & 1.1000 \\
\hline $314-320$ & LAKALRM & 0.6714 & LAKCLRL & 1.0429 \\
\hline
\end{tabular}


Continued SUPPLEMENTARY FILE 2

\begin{tabular}{|c|c|c|c|c|}
\hline $315-321$ & AKALRMS & 0.0143 & AKCLRLS & 0.3857 \\
\hline $316-322$ & KALRMSG & -0.3000 & KCLRLSG & 0.0714 \\
\hline $317-323$ & ALRMSGG & 0.2000 & CLRLSGG & 0.5714 \\
\hline $318-324$ & LRMSGGD & -0.5571 & LRLSGGD & -0.2857 \\
\hline $319-325$ & RMSGGDH & -1.5571 & RLSGGDH & -1.2857 \\
\hline $320-326$ & MSGGDHL & -0.3714 & LSGGDHL & -0.1000 \\
\hline $321-327$ & SGGDHLH & -1.1000 & SGGDHLH & -1.1000 \\
\hline $322-328$ & GGDHLHS & -1.1000 & GGDHLHS & -1.1000 \\
\hline $323-329$ & GDHLHSG & -1.1000 & GDHLHSG & -1.1000 \\
\hline $324-330$ & DHLHSGT & -1.1429 & DHLHSGT & -1.1429 \\
\hline $325-331$ & HLHSGTV & -0.0429 & HLHSGTV & -0.0429 \\
\hline $326-332$ & LHSGTVV & 1.0143 & LHSGTVV & 1.0143 \\
\hline $327-333$ & HSGTVVG & 0.4143 & HSGTVVG & 0.4143 \\
\hline $328-334$ & SGTVVGK & 0.3143 & SGTVVGK & 0.3143 \\
\hline $329-335$ & GTVVGKL & 0.9714 & GTVVGKL & 0.9714 \\
\hline $330-336$ & TVVGKLE & 0.5286 & TVVGKLE & 0.5286 \\
\hline $331-337$ & VVGKLEG & 0.5714 & VVGKLEG & 0.5714 \\
\hline $332-338$ & VGKLEGE & -0.5286 & VGKLEGD & -0.5286 \\
\hline $333-339$ & GKLEGER & -1.7714 & GKLEGDK & -1.6857 \\
\hline $334-340$ & KLEGERE & -2.2143 & KLEGDKA & -1.3714 \\
\hline $335-341$ & LEGEREV & -1.0571 & LEGDKAS & -0.9286 \\
\hline $336-342$ & EGEREVT & -1.7000 & EGDKAST & -1.5714 \\
\hline $337-343$ & GEREVTL & -0.6571 & GDKASTL & -0.5286 \\
\hline $338-344$ & EREVTLG & -0.6571 & DKASTLG & -0.5286 \\
\hline $339-345$ & REVTLGF & 0.2429 & KASTLGF & 0.3714 \\
\hline $340-346$ & EVTLGFV & 1.4857 & ASTLGFV & 1.5286 \\
\hline $341-347$ & VTLGFVD & 1.4857 & STLGFVD & 0.7714 \\
\hline $342-348$ & TLGFVDL & 1.4286 & TLGFVDL & 1.4286 \\
\hline $343-349$ & LGFVDLM & 1.8000 & LGFVDLM & 1.8000 \\
\hline $344-350$ & GFVDLMR & 0.6143 & GFVDLMR & 0.6143 \\
\hline $345-351$ & FVDLMRD & 0.1714 & FVDLMRE & 0.1714 \\
\hline $346-352$ & VDLMRDD & -0.7286 & VDLMRED & -0.7286 \\
\hline $347-353$ & DLMRDDY & -1.5143 & DLMREDH & -1.7857 \\
\hline $348-354$ & LMRDDYV & -0.4143 & LMREDHI & -0.6429 \\
\hline $349-355$ & MRDDYVE & -1.4571 & MREDHIE & -1.6857 \\
\hline $350-356$ & RDDYVEK & -2.2857 & REDHIEA & -1.7000 \\
\hline $351-357$ & DDYVEKD & -2.1429 & EDHIEAD & -1.5571 \\
\hline $352-358$ & DYVEKDR & -2.2857 & DHIEADR & -1.7000 \\
\hline $353-359$ & YVEKDRS & -1.9000 & HIEADRS & -1.3143 \\
\hline $354-360$ & VEKDRSR & -2.3571 & IEADRSR & -1.5000 \\
\hline $355-361$ & EKDRSRG & -3.0143 & EADRSRG & -2.2000 \\
\hline $356-362$ & KDRSRGI & -1.8714 & ADRSRGV & -1.1000 \\
\hline $357-363$ & DRSRGIY & -1.5000 & DRSRGVF & -0.9571 \\
\hline $358-364$ & RSRGIYF & -0.6000 & RSRGVFF & -0.0571 \\
\hline $359-365$ & SRGIYFT & -0.0571 & SRGVFFT & 0.4857 \\
\hline $360-366$ & RGIYFTQ & -0.4429 & RGVFFTQ & 0.1000 \\
\hline $361-367$ & GIYFTQD & -0.3000 & GVFFTQD & 0.2429 \\
\hline $362-368$ & IYFTQDW & -0.3714 & VFFTQDW & 0.1714 \\
\hline $363-369$ & YFTQDWC & -0.6571 & FFTQDWA & -0.1714 \\
\hline $364-370$ & FTQDWCS & -0.5857 & FTQDWAS & -0.6857 \\
\hline $365-371$ & TQDWCSM & -0.7143 & TQDWASM & -0.8143 \\
\hline $366-372$ & QDWCSMP & -0.8429 & QDWASMP & -0.9429 \\
\hline $367-373$ & DWCSMPG & -0.4000 & DWASMPG & -0.5000 \\
\hline
\end{tabular}


Continued SUPPLEMENTARY FILE 2

\begin{tabular}{|c|c|c|c|c|}
\hline $368-374$ & WCSMPGV & 0.7000 & WASMPGV & 0.6000 \\
\hline $369-375$ & CSMPGVM & 1.1000 & ASMPGVL & 1.2714 \\
\hline $370-376$ & SMPGVMP & 0.5143 & SMPGVLP & 0.7857 \\
\hline $371-377$ & MPGVMPV & 1.2286 & MPGVLPV & 1.5000 \\
\hline $372-378$ & PGVMPVA & 1.2143 & PGVLPVA & 1.4857 \\
\hline $373-379$ & GVMPVAS & 1.3286 & GVLPVAS & 1.6000 \\
\hline $374-380$ & VMPVASG & 1.3286 & VLPVASG & 1.6000 \\
\hline $375-381$ & MPVASGG & 0.6714 & LPVASGG & 0.9429 \\
\hline $376-382$ & PVASGGI & 1.0429 & PVASGGI & 1.0429 \\
\hline $377-383$ & VASGGIH & 0.8143 & VASGGIH & 0.8143 \\
\hline $378-384$ & ASGGIHV & 0.8143 & ASGGIHV & 0.8143 \\
\hline $379-385$ & SGGIHVW & 0.4286 & SGGIHVW & 0.4286 \\
\hline $380-386$ & GGIHVWH & 0.0857 & GGIHVWH & 0.0857 \\
\hline $381-387$ & GIHVWHM & 0.4143 & GIHVWHM & 0.4143 \\
\hline $382-388$ & IHVWHMP & 0.2429 & IHVWHMP & 0.2429 \\
\hline 383-389 & HVWHMPA & -0.1429 & HVWHMPA & -0.1429 \\
\hline $384-390$ & VWHMPAL & 0.8571 & VWHMPAL & 0.8571 \\
\hline $385-391$ & WHMPALV & 0.8571 & WHMPALV & 0.8571 \\
\hline 386-392 & HMPALVE & 0.4857 & HMPALVE & 0.4857 \\
\hline $387-393$ & MPALVEI & 1.5857 & MPALVEI & 1.5857 \\
\hline 388-394 & PALVEIF & 1.7143 & PALVEIF & 1.7143 \\
\hline $389-395$ & ALVEIFG & 1.8857 & ALVEIFG & 1.8857 \\
\hline $390-396$ & LVEIFGD & 1.1286 & LVEIFGD & 1.1286 \\
\hline $391-397$ & VEIFGDD & 0.0857 & VEIFGDD & 0.0857 \\
\hline $392-398$ & EIFGDDA & -0.2571 & EIFGDDS & -0.6286 \\
\hline 393-399 & IFGDDAC & 0.6000 & IFGDDSV & 0.4714 \\
\hline $394-400$ & FGDDACL & 0.5000 & FGDDSVL & 0.3714 \\
\hline $395-401$ & GDDACLQ & -0.4000 & GDDSVLQ & -0.5286 \\
\hline $396-402$ & DDACLQF & 0.0571 & DDSVLQF & -0.0714 \\
\hline $397-403$ & DACLQFG & 0.5000 & DSVLQFG & 0.3714 \\
\hline $398-404$ & ACLQFGG & 0.9429 & SVLQFGG & 0.8143 \\
\hline $399-405$ & CLQFGGG & 0.6286 & VLQFGGG & 0.8714 \\
\hline $400-406$ & LQFGGGT & 0.1714 & LQFGGGT & 0.1714 \\
\hline $401-407$ & QFGGGTL & 0.1714 & QFGGGTL & 0.1714 \\
\hline $402-408$ & FGGGTLG & 0.6143 & FGGGTLG & 0.6143 \\
\hline 403-409 & GGGTLGH & -0.2429 & GGGTLGH & -0.2429 \\
\hline $404-410$ & GGTLGHP & -0.4143 & GGTLGHP & -0.4143 \\
\hline $405-411$ & GTLGHPW & -0.4857 & GTLGHPW & -0.4857 \\
\hline $406-412$ & TLGHPWG & -0.4857 & TLGHPWG & -0.4857 \\
\hline $407-413$ & LGHPWGN & -0.8857 & LGHPWGN & -0.8857 \\
\hline $408-414$ & GHPWGNA & -1.1714 & GHPWGNA & -1.1714 \\
\hline $409-415$ & HPWGNAP & -1.3429 & HPWGNAP & -1.3429 \\
\hline $410-416$ & PWGNAPG & -0.9429 & PWGNAPG & -0.9429 \\
\hline $411-417$ & WGNAPGA & -0.4571 & WGNAPGA & -0.4571 \\
\hline $412-418$ & GNAPGAA & -0.0714 & GNAPGAT & -0.4286 \\
\hline $413-419$ & NAPGAAA & 0.2429 & NAPGATA & -0.1143 \\
\hline $414-420$ & APGAAAN & 0.2429 & APGATAN & -0.1143 \\
\hline $415-421$ & PGAAANR & -0.6571 & PGATANR & -1.0143 \\
\hline $416-422$ & GAAANRV & 0.1714 & GATANRV & -0.1857 \\
\hline $417-423$ & AAANRVA & 0.4857 & ATANRVA & 0.1286 \\
\hline $418-424$ & AANRVAL & 0.7714 & TANRVAL & 0.4143 \\
\hline $419-425$ & ANRVALE & 0.0143 & ANRVALE & 0.0143 \\
\hline $420-426$ & NRVALEA & 0.0143 & NRVALEA & 0.0143 \\
\hline
\end{tabular}


Continued SUPPLEMENTARY FILE 2

\begin{tabular}{|c|c|c|c|c|}
\hline $421-427$ & RVALEAC & 0.8714 & RVALEAC & 0.8714 \\
\hline $422-428$ & VALEACT & 1.4143 & VALEACV & 2.1143 \\
\hline $423-429$ & ALEACTQ & 0.3143 & ALEACVQ & 1.0143 \\
\hline $424-430$ & LEACTQA & 0.3143 & LEACVQA & 1.0143 \\
\hline $425-431$ & EACTQAR & -0.8714 & EACVQAR & -0.1714 \\
\hline $426-432$ & ACTQARN & -0.8714 & ACVQARN & -0.1714 \\
\hline $427-433$ & CTQARNE & -1.6286 & CVQARNE & -0.9286 \\
\hline $428-434$ & TQARNEG & -2.0429 & VQARNEG & -1.3429 \\
\hline $429-435$ & QARNEGR & -2.5857 & QARNEGR & -2.5857 \\
\hline $430-436$ & ARNEGRD & -2.5857 & ARNEGRD & -2.5857 \\
\hline $431-437$ & RNEGRDL & -2.3000 & RNEGRDL & -2.3000 \\
\hline $432-438$ & NEGRDLA & -1.4000 & NEGRDLY & -1.8429 \\
\hline $433-439$ & EGRDLAR & -1.5429 & EGRDLYR & -1.9857 \\
\hline $434-440$ & GRDLARE & -1.5429 & GRDLYRE & -1.9857 \\
\hline $435-441$ & RDLAREG & -1.5429 & RDLYREG & -1.9857 \\
\hline $436-442$ & DLAREGG & -0.9571 & DLYREGG & -1.4000 \\
\hline $437-443$ & LAREGGD & -0.9571 & LYREGGD & -1.4000 \\
\hline $438-444$ & AREGGDV & -0.9000 & YREGGDI & -1.3000 \\
\hline $439-445$ & REGGDVI & -0.5143 & REGGDIL & -0.5714 \\
\hline $440-446$ & EGGDVIR & -0.5143 & EGGDILR & -0.5714 \\
\hline $441-447$ & GGDVIRS & -0.1286 & GGDILRE & -0.5714 \\
\hline $442-448$ & GDVIRSA & 0.1857 & GDILREA & -0.2571 \\
\hline $443-449$ & DVIRSAC & 0.6000 & DILREAG & -0.2571 \\
\hline $444-450$ & VIRSACK & 0.5429 & ILREAGK & -0.3143 \\
\hline $445-451$ & IRSACKW & -0.1857 & LREAGKW & -1.0857 \\
\hline $446-452$ & RSACKWS & -0.9429 & REAGKWS & -1.7429 \\
\hline $447-453$ & SACKWSP & -0.5286 & EAGKWSP & -1.3286 \\
\hline $448-454$ & ACKWSPE & -0.9143 & AGKWSPE & -1.3286 \\
\hline $449-455$ & CKWSPEL & -0.6286 & GKWSPEL & -1.0429 \\
\hline $450-456$ & KWSPELA & -0.7286 & KWSPELA & -0.7286 \\
\hline $451-457$ & WSPELAA & 0.0857 & WSPELAA & 0.0857 \\
\hline $452-458$ & SPELAAA & 0.4714 & SPELAAA & 0.4714 \\
\hline $453-459$ & PELAAAC & 0.9429 & PELAAAL & 1.1286 \\
\hline $454-460$ & ELAAACE & 0.6714 & ELAAALD & 0.8571 \\
\hline $455-461$ & LAAACEV & 1.7714 & LAAALDL & 1.9000 \\
\hline $456-462$ & AAACEVW & 1.1000 & AAALDLW & 1.2286 \\
\hline $457-463$ & AACEVWK & 0.2857 & AALDLWK & 0.4143 \\
\hline $458-464$ & ACEVWKE & -0.4714 & ALDLWKE & -0.3429 \\
\hline $459-465$ & CEVWKEI & -0.0857 & LDLWKEI & 0.0429 \\
\hline $460-466$ & EVWKEIK & -1.0000 & DLWKEIK & -1.0571 \\
\hline $461-467$ & VWKEIKF & -0.1000 & LWKEIKF & -0.1571 \\
\hline $462-468$ & WKEIKFE & -1.2000 & WKEIKFE & -1.2000 \\
\hline $463-469$ & KEIKFEF & -0.6714 & KEIKFEF & -0.6714 \\
\hline $464-470$ & EIKFEFD & -0.6143 & EIKFEFE & -0.6143 \\
\hline $465-471$ & IKFEFDT & -0.2143 & IKFEFET & -0.2143 \\
\hline $466-472$ & KFEFDTI & -0.2143 & KFEFETM & -0.5857 \\
\hline $467-473$ & FEFDTID & -0.1571 & FEFETMD & -0.5286 \\
\hline $468-474$ & EFDTIDK & -1.1143 & EFETMDK & -1.4857 \\
\hline $469-475$ & FDTIDKL & -0.0714 & FETMDKL & -0.4429 \\
\hline
\end{tabular}

a Residue numbering is based on Chlamydomonas RbcL

${ }^{\mathrm{b}} \mathrm{Syn}$ echocococcus RbcL is shorter by 3 residues at the N-terminus compared to Chlamydomonas RbcL 